\title{
Article \\ The Photovoltaic Performance of Sensitizers for Organic Solar Cells Containing Fluorinated Chalcones with Different Halogen Substituents
}

\author{
Siti Nabilla Aliya Mohd Nizar ${ }^{1}$, Siti Noor Farhana Ab Rahman ${ }^{1}$, Muhamad Fikri Zaini ${ }^{2}$, \\ Ainizatul Husna Anizaim 1, Ibrahim Abdul Razak 1,*D and Suhana Arshad 1,*D \\ 1 X-ray Crystallography Unit, School of Physics, Universiti Sains Malaysia, Gelugor 11800, Penang, Malaysia; \\ snabillaaliya@gmail.com (S.N.A.M.N.); snfarhanaabrahman@gmail.com (S.N.F.A.R.); \\ ainizatulhusnaanizaim@gmail.com (A.H.A.) \\ 2 Pusat GENIUS@Pintar Negara, Universiti Kebangsaan Malaysia, Bangi 43600, Selangor, Malaysia; \\ fikrizaini@ukm.edu.my \\ * Correspondence: suhanaarshad@usm.my (S.A.); arazaki@usm.my (I.A.R.)
}

Citation: Mohd Nizar, S.N.A.; Ab Rahman, S.N.F.; Zaini, M.F.; Anizaim, A.H.; Abdul Razak, I.; Arshad, S. The Photovoltaic Performance of Sensitizers for Organic Solar Cells Containing Fluorinated Chalcones with Different Halogen Substituents. Crystals 2021, 11, 1357. https:// doi.org/10.3390/cryst11111357

Academic Editors: Thomas M.

Klapötke and Saripally

Sudhaker Reddy

Received: 29 September 2021

Accepted: 2 November 2021

Published: 8 November 2021

Publisher's Note: MDPI stays neutral with regard to jurisdictional claims in published maps and institutional affiliations.

Copyright: (c) 2021 by the authors. Licensee MDPI, Basel, Switzerland. This article is an open access article distributed under the terms and conditions of the Creative Commons Attribution (CC BY) license (https:// creativecommons.org/licenses/by/ $4.0 /)$.
Abstract: Two newly halogenated chalcones, derivatives of $\mathrm{C}_{15} \mathrm{H}_{10} \mathrm{ClFO}(\mathbf{C H}-\mathrm{ClF})$ and $\mathrm{C}_{15} \mathrm{H}_{10} \mathrm{~F}_{2} \mathrm{O}$ (CH-FF), were synthesized using the Claisen-Schmidt condensation method. Both compounds were crystallized using a slow evaporation method, forming a monoclinic crystal system with a space group of $P 2_{1}$ and $P 2_{1} / c$, respectively. The compounds were further analyzed using spectroscopic techniques such as Fourier Transform Infrared (FTIR), Nuclear Magnetic Resonance (NMR), and UltravioletVisible (UV-vis) analyses. The single crystal X-ray diffraction method revealed the existence of $\mathrm{C}-\mathrm{H} \cdots \mathrm{O}$ and $\mathrm{C}-\mathrm{H} \cdots \mathrm{F}$ intermolecular interactions in CH-FF. Hirshfeld surface analysis was performed to confirm the existence of intermolecular interactions in the compounds. The molecular geometries obtained from the X-ray structure determination were further used to optimize the structures using density functional theory (DFT), with the B3LYP/6-311G++(d,p) basis set in the ground state. The TD-DFT/B3LYP method was used to obtain the electronic properties and the HOMO-LUMO energy gap. Both compounds exhibited A- $\pi$-A architecture with different halogen substituents in which the $\mathbf{C H}-\mathbf{F F}$, containing -fluoro substituents, possessed good electron injection ability due to its electronegative properties. This increased the flow of the charge transfer for the dye regeneration process and enhanced the efficiency of the dye-sensitized solar cell (DSSC).

Keywords: halogenated chalcone; single crystal; DFT; A- $\pi$-A organic dye; DSSC

\section{Introduction}

There has been much research into organic material due to its variety of design selections, which can be used with suitable reactants through simple procedures and low synthesis cost $[1,2]$. Chalcones are organic materials from the flavonoid family with a molecular structure that can be modified and synthesized using assorted heterocyclic compounds [3]. Chalcones are constructed by planar $\pi$-conjugated systems connected with aromatic rings at both ends of the enone bridge [4]. As the substituent components of chalcone can be varied, this leads to spectroscopic and characterization analysis regarding structural planarity, the involvement of intermolecular interaction, and the intramolecular charge transfer (ICT) of the compounds [5]. Additionally, the existence of a donor (D) and acceptor (A) linked via the $\alpha, \beta$ - unsaturated keto group as $D-A-D, A-D-A, D-\pi-A$, $\mathrm{D}-\pi-\mathrm{D}$ and $\mathrm{A}-\pi-\mathrm{A}$ construct a chalcone with a good charge transfer configuration for use as a dye-sensitizer in solar cell applications [6-8].

Many researchers have employed chalcone derivatives as sensitizers [9-14] due to their properties and performance. The ability of various substituents to be anchored at different positions in chalcone derivatives enables studies on their light harvesting potential 
for DSSC applications [15]. The DSSC is a third-generation solar cell that is economical and environmentally friendly, with excellent cell flexibility compared to the silicon-based solar cell [16]. As a newly developed photovoltaic technology, the invention of the DSSC was inspired by the photosynthesis process that converts sunlight into valuable products, in our case, electrical energy $[16,17]$. The DSSC has become an increasingly popular alternative energy source since its development in the 1970s by Gerischer and Tributsch [18].

In order to contribute to this work, two chalcone derivatives, namely (E)-3-(3-chlorophenyl)1-(4-fluorophenyl)prop-2-en-1-one, $\mathrm{C}_{15} \mathrm{H}_{10} \mathrm{ClFO}$ (CH-ClF) and (E)-3-(3-fluorophenyl)-1-(4fluorophenyl)prop-2-en-1-one, $\mathrm{C}_{15} \mathrm{H}_{10} \mathrm{~F}_{2} \mathrm{O}$ (CH-FF) were synthesized in order to study their chemical properties and potency as dye-sensitizers in DSSCs. $\mathbf{C H}-\mathbf{C l F}$ and $\mathbf{C H}-\mathbf{F F}$ represent similar structural designs, with -chloro and -fluoro attachments on the corresponding compounds, respectively. Electronegativity is defined as the ability of the atom to attract electron density when forming the chemical bond. The fluorine atom is more negative than chlorine [19]. A compound with a higher electronegativity increases the ability of electron transfer within the molecule [20-22], thus influencing the low gap between HOMO and LUMO energy levels [10]. From this perspective, we successfully proved that CH-FF, with the substitution of -fluoro on both aromatic rings of the chalcone derivative, contributed to a higher DSSC efficiency than $\mathbf{C H}-\mathrm{ClF}$. Additionally, the presence of hydrogen bonds in $\mathrm{CH}-\mathrm{FF}$ provided good electronic communication between the molecules, resulting in an excellent DSSC power conversion.

\section{Methodology}

\subsection{Synthesis of Halogenated Chalcone Derivatives}

Initially, the synthesis of halogenated chalcone derivatives was achieved by the condensation of $4^{\prime}$-fluoroacetophenone $(0.01 \mathrm{~mol})$ with corresponding benzaldehydes $(0.01 \mathrm{mmol})$ comprising 3-chlorobenzaldehyde and 3-fluorobenzaldehyde in $60 \mathrm{~mL}$ of ethanol in the presence of a catalytic amount of sodium hydroxide solution $(5 \mathrm{~mL}, 20 \%)$. The solution was continuously stirred for about 5-6 h at room temperature. The resultant precipitates were filtered, washed successively with distilled water, and recrystallized from acetone to obtain the corresponding chalcone (Scheme 1). Figure 1 shows the single crystals of the compounds, which were suitable for X-ray structural analysis.<smiles>[R]c1cccc(/C=C/C(=O)c2ccc(F)cc2)c1</smiles>

Scheme 1. The synthesis route of the title compounds.

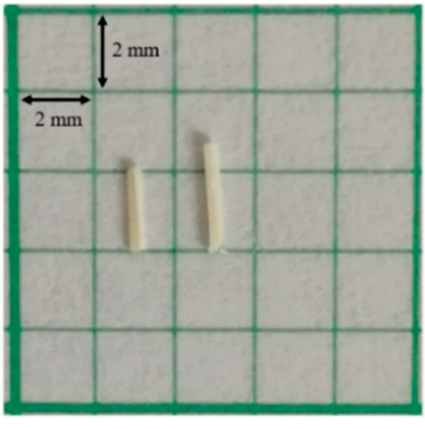

(a)

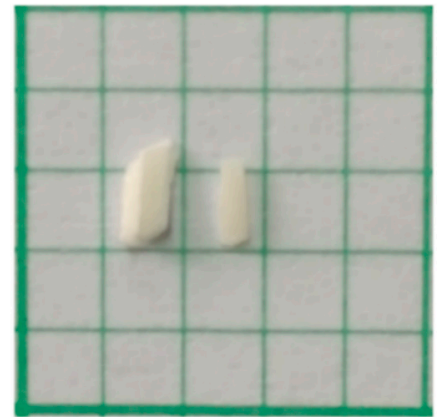

(b)

Figure 1. The single crystals of the compound (a) $\mathrm{CH}-\mathrm{ClF}$ and (b) $\mathrm{CH}-\mathrm{FF}$.

\subsection{Spectroscopy Analysis}

The infrared spectra were analyzed using a PerkinElmer GX Frontier Spectrophotometer in the range of $400-4000 \mathrm{~cm}^{-1}$, with a $\mathrm{KBr}$ pellet to transcribe the vibrational 
modes consistent with the functional groups. In addition, ${ }^{1} \mathrm{H}$ NMR and ${ }^{13} \mathrm{C}$ NMR spectra studies were recorded in DMSO- $d_{6}$ by a Bruker 500 and a $125 \mathrm{MHz}$ Avance III spectrometer, respectively. The chemical shifts $(\delta)$ were utilized in parts per million (ppm) downfield from the internal tetramethysilane (TMS) internal reference. UV-vis spectroscopy was performed in acetonitrile solution using a SHIMADZU UV-1800 Spectrophotometer in the spectral region of 200-900 $\mathrm{nm}$ to study the electronic transition within the compounds.

\subsection{X-ray Crystallography Analysis}

X-ray analysis was performed on single suitable crystals with an APEXII Duo CCD area detector using Mo K $\alpha$ radiation $(\lambda=0.71073 \AA$ ). Good quality crystals were selected under the microscope and used for data collection. Data collection was performed using APEX2 software [23], whereas the cell refinement and data reduction were performed using SAINT software [23]. The crystal structures were solved by the Direct Method using the program SHELXTL [24] and refined by the full-matrix least squares technique on $F^{2}$ using anisotropic displacement parameters by SHELXTL [24]. Absorption corrections were applied to the final crystal data using SADABS software [23]. All geometrical calculations were carried out using the program PLATON [25]. The molecular graphics were drawn using SHELXTL [24] and the Mercury program [26]. The non-hydrogen atoms were refined anisotropically. All the hydrogen atoms were positioned geometrically $(\mathrm{C}-\mathrm{H}=0.93 \AA)$ and refined using the riding model $U_{\mathrm{iso}}(\mathrm{H})=1.2 U_{\mathrm{eq}}(\mathrm{C})$, meaning that the isotropic displacement parameters were set to $1.2(\mathrm{C})$ times the equivalent isotropic $\mathrm{U}$ values of the parent carbon atoms. Table 1 provides a summary of the crystal data and relevant refinement parameters of the title compounds.

Table 1. Crystallographic collection and refinement data for compounds $\mathrm{CH}-\mathrm{ClF}$ and $\mathrm{CH}-\mathrm{FF}$.

\begin{tabular}{|c|c|c|}
\hline Parameters & $\mathrm{CH}-\mathrm{ClF}$ & CH-FF \\
\hline CCDC deposition numbers & 1521381 & 1521383 \\
\hline Molecular formula & $\mathrm{C}_{15} \mathrm{H}_{10} \mathrm{ClFO}$ & $\mathrm{C}_{15} \mathrm{H}_{10} \mathrm{~F}_{2} \mathrm{O}$ \\
\hline Molecular weight & 260.68 & 244.23 \\
\hline Crystal system & Monoclinic & Monoclinic \\
\hline Space group & $P 2_{1}$ & $P 2_{1} / c$ \\
\hline$a / \AA$ & $11.4052(10)$ & $11.735(2)$ \\
\hline$b / \AA$ & $3.9037(3)$ & $3.9383(8)$ \\
\hline$c / \AA$ & $13.8077(12)$ & $25.862(4)$ \\
\hline$\beta /^{\circ}$ & $95.2670(18)$ & $100.794(4)$ \\
\hline$V / \AA^{3}$ & $1386.42(9)$ & $1174.1(4)$ \\
\hline Z & 2 & 4 \\
\hline$D_{\text {calc }}\left(\mathrm{Mg} \mathrm{m}^{-3}\right)$ & $1 . \overline{4} 14$ & 1.382 \\
\hline Crystal Dimensions (mm) & $0.57 \times 0.20 \times 0.09$ & $0.68 \times 0.22 \times 0.20$ \\
\hline$\mu\left(\mathrm{mm}^{-1}\right)$ & 0.31 & 0.11 \\
\hline Radiation $\lambda(\AA)$ & 0.71073 & 0.71073 \\
\hline$F(000)$ & 268 & 504 \\
\hline$T_{\min } / T_{\max }$ & $0.8103 / 0.8835$ & $0.8068 / 0.9393$ \\
\hline Reflections measured & 13,236 & 12,518 \\
\hline Ranoes/indices (h $k$ l) & $h=-16 \rightarrow 16$ & $h=-16 \rightarrow 16$ \\
\hline Kanges / inaices $(n, \kappa, l)$ & $\begin{array}{l}\kappa=-5 \rightarrow 5 \\
l=-19 \rightarrow 19\end{array}$ & $\begin{array}{c}k=-2 \rightarrow 5 \\
l=-36 \rightarrow 36\end{array}$ \\
\hline$\theta$ limit $\left({ }^{\circ}\right)$ & $1.5-30.2$ & $2.2-30.0$ \\
\hline Unique reflections & 3616 & 3430 \\
\hline Observed reflections $(I>2 \sigma(I))$ & 2664 & 1823 \\
\hline Parameters & 163 & 163 \\
\hline$R_{1}[\mathrm{a}], w R_{2}[\mathrm{~b}][I \geq 2 \sigma(I)]$ & $0.038 / 0.110^{\mathrm{i}}$ & $0.048 / 0.170^{\mathrm{ii}}$ \\
\hline Goodness of fit [c] on $F^{2}$ & 1.05 & 1.03 \\
\hline$R_{\text {int }}$ & 0.029 & 0.037 \\
\hline Largest diff. peak and hole, e $/ \AA^{-3}$ & 0.21 and -0.13 & 0.15 and -0.15 \\
\hline
\end{tabular}

[i] $\mathrm{w}=1 /\left[\sigma^{2}\left(\mathrm{~F}_{\mathrm{o}}{ }^{2}\right)+(0.0525 \mathrm{P})^{2}+0.0304 \mathrm{P}\right]$, [ii] $\mathrm{w}=1 /\left[\sigma^{2}\left(\mathrm{~F}_{\mathrm{o}}{ }^{2}\right)+(0.074 \mathrm{P})^{2}+0.0988 \mathrm{P}\right]$, where $\mathrm{P}=\left(\mathrm{F}_{\mathrm{o}}{ }^{2}+2 \mathrm{~F}_{\mathrm{c}}{ }^{2}\right) / 3$; [a] $\mathrm{R}=\Sigma|| \mathrm{F}_{\mathrm{o}}|-| \mathrm{F}_{\mathrm{c}}|| / \Sigma\left|\mathrm{F}_{\mathrm{o}}\right|,[\mathrm{b}]_{\mathrm{w}} \mathrm{R}=\left\{\mathrm{w} \Sigma\left(\left|\mathrm{F}_{\mathrm{o}}\right|-\left|\mathrm{F}_{\mathrm{c}}\right|\right)^{2} / \Sigma \mathrm{w}\left|\mathrm{F}_{\mathrm{o}}\right|^{2}\right\}^{1 / 2},[\mathrm{c}]$ GOF $=\left\{\Sigma \mathrm{w}\left(\left|\mathrm{F}_{\mathrm{o}}\right|-\left|\mathrm{F}_{\mathrm{c}}\right|\right)^{2} /(\mathrm{n}-\mathrm{p})\right\}^{1 / 2}$, where $\mathrm{n}$ is the number of reflections and $\mathrm{p}$ the total number of parameters refined. 


\subsection{Hirshfeld Surface Analysis}

Hirshfeld surfaces and the associated 2D fingerprint plots were calculated using Crystal Explorer 3.1 [27]. This approach attempts to present a graphical tool for the visualization and understanding of intermolecular interactions through the identification of all close contacts. The Hirshfeld surface provides the close interaction of the crystal structure, which is summarized in a 2D fingerprint plot. The distances from the Hirshfeld surface to the nearest atoms outside and inside the surface are represented as $d_{i}$ and $d_{e}$, respectively. The blue refers to the low occurrence of the $\left(d_{i}, d_{e}\right)$ pair and the grey is the outline of the full fingerprint [28]. The parameters such as $d_{i}, d_{e}$ and the Van der Waals radii $\left(r^{\mathrm{vdW}}\right)$ can be correlated into Equation (1) and act as an identification tool for specific intermolecular interactions via the color-coding system. In addition, a shape index was also used as a qualitative measure of molecular shape, explicitly in regions where the total curvature (or the curvedness) was very low.

$$
d_{n o r m}=\frac{d_{i}-r_{i}^{v d W}}{r_{i}^{v d W}}+\frac{d_{e}-r_{e}^{v d W}}{r_{e}^{v d W}}
$$

\subsection{Computational Analysis}

The geometrical parameters of the compound were analyzed via X-ray refinement data using the Direct method. The molecular geometries were further optimized using Gaussian09W application software to obtain all the theoretical calculations [29] by utilizing the Becke three-parameter hybrid plus combined with the Lee-Yang-Parr correlation functional studies. The DFT calculations deployed a hybrid density functional B3LYP with the $6-311++G(d, p)$ base set. Additionally, the time-dependent density functional theory (TD-DFT) was used to extract information regarding charge transfer between the highest occupied molecular orbital (HOMO) and lowest unoccupied molecular orbital (LUMO) using the same base set. The calculation was conducted in an isolated condition by applying the integral equation formalism polarizable continuum model (IEFPCM) in a specific acetonitrile solvent environment.

\subsection{Dye-Synthesized Solar Cell (DSSC) Fabrication}

The preparation of DSSCs was conducted following the previous fabrication method $[9,10]$. A full set of DSSC kits was purchased from Solaronix for the fabrication process.

\subsubsection{Preparation of Halogenated Chalcones as Organic Dye Sensitizers}

The preparation of organic dye sensitizer began by dissolving $10^{-2} \mathrm{M}$ of $\mathrm{CH}-\mathrm{ClF}$ and CH-FF precipitate into $5 \mathrm{~mL}$ of acetonitrile for each compound. A small amount of chenodeoxycholic acid (ratio 10:1) was added into the dye solution as a coadditive to enhance the DSSC conversion [30]. All steps were conducted with a minimal presence of light to preserve the properties of the dye-sensitizers.

\subsubsection{Preparation of Ruthenium Standard Dye as a Reference}

A reference standard dye, cis-diisothiocyanato-bis(2,20-bipyridyl-4,40-dicarboxylato) ruthenium(II) bis(tetrabutylammonium), or, N719 was prepared as a reference for the solar cell efficiency study. The standard dye was dissolved into a $10 \mathrm{~mL}$ acetonitrile solvent with a small amount of chenodeoxycholic acid (10:1 ratio). Due to the light sensitivity of N719 dye, the preparation was conducted in a dark room to avoid any direct contact with light.

\subsubsection{Preparation of DSSC Fabrication}

A working electrode composed of $\mathrm{TiO}_{2}(6 \mathrm{~mm} \times 6 \mathrm{~mm}$ area $)$ coated with $\mathrm{FTO}$ glass was sensitized by immersion into the respective dye solution of each compound overnight. Once ready, the samples were rinsed using the residual acetonitrile to extract the excessive dye and the remaining dye solution was dropped onto the $\mathrm{TiO}_{2}$ area using the drop casting method while being dried in the hot airflow. The photoanode and counter electrode were 
attached together by placing a sealing film made from Meltonix 1170 with $60 \mu \mathrm{m}$ thickness in between the electrodes to form a sandwich-type cell. The cell was again placed on the hot plate in order to melt the film via gradual application of pressure. Iodolyte AN-50 electrolyte solution was injected into both sandwich cells through a predrilled hole located at the surface of the counter electrode. Then, the holes were covered by sealing films to avoid the electrolyte being leaked and the dyes drying out. The basic components of the fabricated DSSC are illustrated in Figure 2 ; a picture of the DSSCs assembled by the $\mathbf{C H}-\mathbf{C l F}$ and $\mathbf{C H}-\mathbf{F F}$ sensitizers is shown in Figure S1 in the Supplementary Information.

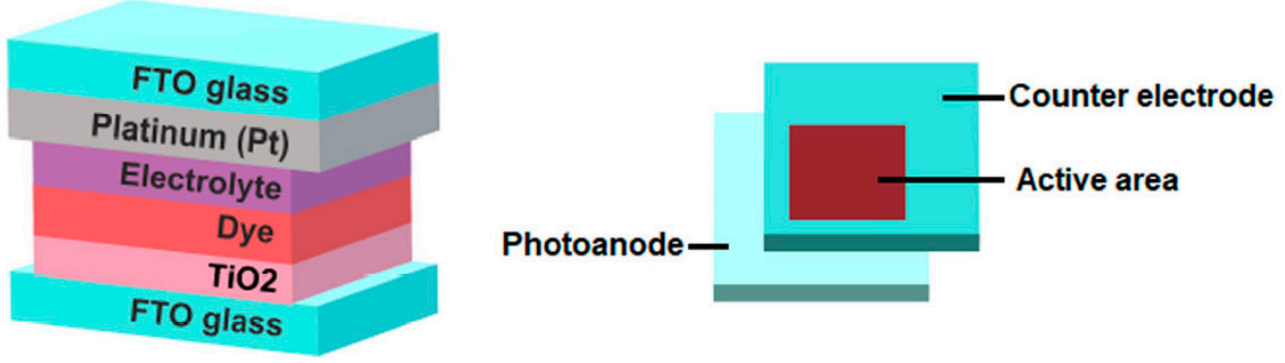

Figure 2. Illustrative diagram of the DSSC components [9].

The sensitized cells were analyzed by a Keithley 2400 solar simulator in order to determine the output voltage and the current reading of the tested compounds, under irradiation of AM 1.5 simulated sunlight (CHF-XM-500 W) with an intensity of $100 \pm 3 \mathrm{~mW} / \mathrm{cm}^{2}$.

\section{Results and Discussion}

\subsection{Fourier Transform Infrared Spectroscopy (FTIR) Studies}

FTIR study is an analytical method conducted to interpret the existence of various functional groups and the vibrational frequency within the compound based on the spectrum [31]. As in our report, the FTIR spectra of $\mathbf{C H}-\mathbf{C l F}$ and $\mathbf{C H}-\mathbf{F F}$ from the experimental analysis are depicted in Figure 3 and summarized in Table 2.

\subsubsection{C-H Vibrations}

The FTIR studies previously reported by Vinaya described that $\mathrm{C}-\mathrm{H}$ stretching vibrations were assigned at a wavenumber of 2800 and $3100 \mathrm{~cm}^{-1}$ [32]. Meanwhile, the absorption bands of $\mathbf{C H}-\mathbf{C l F}$ and $\mathbf{C H}-\mathbf{F F}$ were seen at the frequencies of $3060.5 \mathrm{~cm}^{-1}$ and $3063.5 \mathrm{~cm}^{-1}$, respectively. Both compounds consisted of similar C-H contents, which led to similar wavenumber values. The $\mathrm{C}-\mathrm{H}$ in-plane and $\mathrm{C}-\mathrm{H}$ out-of-plane bending vibrations appeared at 1474-1167 $\mathrm{cm}^{-1}$ and $1023-715 \mathrm{~cm}^{-1}$, respectively [33]. The $\mathrm{C}-\mathrm{H}$ in-plane bending vibrations were observed at 1410,1357, 1301, and $1226 \mathrm{~cm}^{-1}$ in the $\mathrm{CH}-\mathrm{ClF}$ spectrum and $1448,1410.5,1301.5$, and $1226.5 \mathrm{~cm}^{-1}$ in the $\mathbf{C H}-\mathrm{FF}$ spectrum. The C-H out-of-plane bending vibrations were detected at peaks $1000,939.5,879$, and $758.5 \mathrm{~cm}^{-1}$ for $\mathbf{C H}-\mathrm{ClF}$ and $1010.5,897.5,845.5$, and $705 \mathrm{~cm}^{-1}$ for the $\mathbf{C H}$-FF spectrum. Both $\mathrm{C}-\mathrm{H}$ planes were found within the normal wavenumber ranges.

\subsection{2. $\mathrm{C}=\mathrm{O}$ Vibrations}

The carbonyl group existed at the enone bridge of the compounds, contributing to the $\mathrm{C}=\mathrm{O}$ stretching vibration. The $\mathrm{C}=\mathrm{O}$ stretching vibration absorbed IR strongly in the region of 1715-1600 $\mathrm{cm}^{-1}$ [34]. Hence, the wavenumbers of $1684 \mathrm{~cm}^{-1}(\mathrm{CH}-\mathrm{ClF})$ and $1683.5 \mathrm{~cm}^{-1}$ (CH-FF) indicated the presence of $\mathrm{C}=\mathrm{O}$ vibration in the spectral region. The small difference of $0.5 \mathrm{~cm}^{-1}$ between the vibration of $\mathrm{CH}-\mathrm{ClF}$ and $\mathrm{CH}-\mathrm{FF}$ was due to the similar physical position of the carbonyl group in their respective chemical structures. The peaks observed for the $\mathrm{C}=\mathrm{O}$ stretching vibration appeared as a strong band, as a large dipole moment existed due to the carbonyl carbon and oxygen consisting of a large partial positive and negative charge, respectively [9]. 

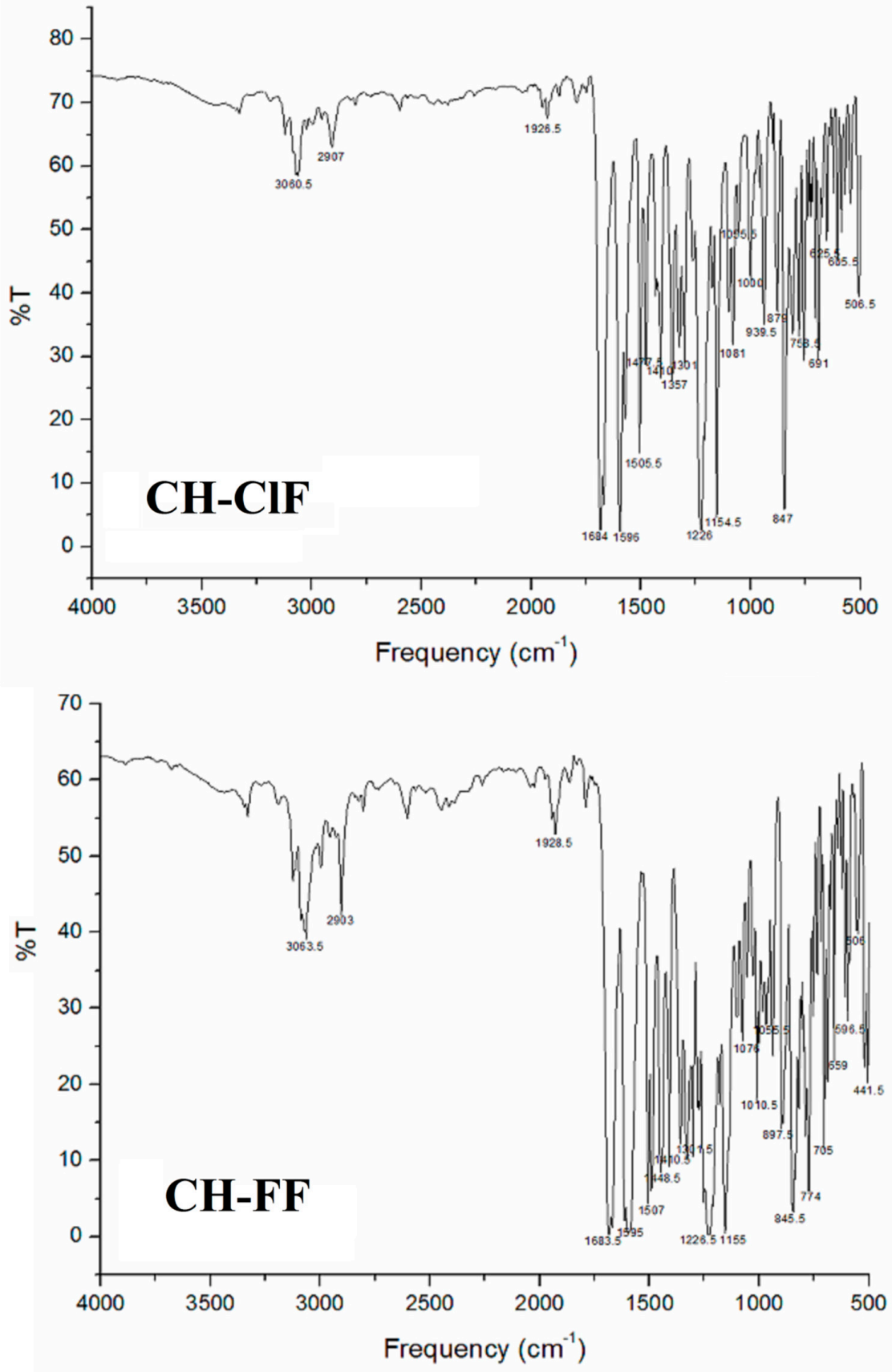

Figure 3. FTIR spectrum of $\mathrm{CH}-\mathrm{ClF}$ and $\mathrm{CH}-\mathrm{FF}$.

Table 2. Summary of the IR vibrational band of $\mathrm{CH}-\mathrm{ClF}$ and $\mathrm{CH}-\mathrm{FF}$.

\begin{tabular}{ccc}
\hline Functional Groups & \multicolumn{2}{c}{ Wavenumber Frequency $\left(\mathbf{c m}^{-\mathbf{1}}\right)$} \\
& $\mathrm{CH}-\mathrm{ClF}$ & $\mathbf{C H}-\mathrm{FF}$ \\
\hline$v \mathrm{C}=\mathrm{O}$ & 1684.0 & 1683.5 \\
\hline$v \mathrm{C}=\mathrm{C}$ & 1596.0 & 1683.0 \\
\hline$v \mathrm{C}-\mathrm{C}$ & 1055.5 & 1055.5 \\
\hline$v \mathrm{C}-\mathrm{Cl}$ & 691.0 & 506.0 \\
\hline$v \mathrm{C}-\mathrm{F}$ & 1154.5 & 1155.0 \\
\hline
\end{tabular}




\subsection{3. $\mathrm{C}=\mathrm{C}$ and $\mathrm{C}-\mathrm{C}$ Vibrations}

For the $C=C$ stretching vibration, the wavenumbers were observed at the $1596 \mathrm{~cm}^{-1}$ and $1683 \mathrm{~cm}^{-1}$ band spectrums of $\mathbf{C H}-\mathrm{ClF}$ and $\mathrm{CH}-\mathrm{FF}$, respectively. The results were interpreted by referring to previous research, which estimated about $1600 \mathrm{~cm}^{-1}$ for the conjugated $\mathrm{C}=\mathrm{C}$ that was bonded to the carbonyl group [35]. As for the $\mathrm{C}-\mathrm{C}$ stretching mode, the electronegativity effect between two carbon atoms caused small peak contributions to the spectrum, which were mostly insignificant [36]. In our studies, we found the vibrational frequencies of $\mathrm{C}-\mathrm{C}$ of $\mathrm{CH}-\mathrm{ClF}$ and $\mathrm{CH}-\mathrm{FF}$ at the same wavenumber, $1055.5 \mathrm{~cm}^{-1}$. This occurred due to the carbon atoms being in the same position in the molecular structure of both compounds, which contributed to their having the same vibrational frequency values.

\subsubsection{C-X Vibrations}

$\mathrm{C}-\mathrm{X}$ vibrations in which $\mathrm{X}$ was specifically known as halogen atoms were found to easily interact with the phenyl ring especially when the halogen atom directly bonded to the benzene ring [37]. The presence of a $\mathrm{C}-\mathrm{Cl}$ bond was found in $\mathrm{CH}-\mathrm{ClF}$ to mark the observed bands at $691 \mathrm{~cm}^{-1}$ and $506 \mathrm{~cm}^{-1}$. The $\mathrm{C}-\mathrm{Cl}$ stretching vibrations were expected to be in the range of 492 and $1234 \mathrm{~cm}^{-1}$ determined by the structure configuration of the compound [38]. Additionally, another halogenated vibrational frequency, which was C-F stretching, contributed a high intensity band and was found in both reported compounds. In $\mathbf{C H}-\mathrm{ClF}$, the C-F stretching mode was interpreted at $1154.5 \mathrm{~cm}^{-1}$, meanwhile in $\mathbf{C H}-\mathbf{F F}$, it was observed at $1155 \mathrm{~cm}^{-1}$; both peaks were found to fall in an assumed range between 1155 to $1330 \mathrm{~cm}^{-1}$ in previous research [36]. The vibration wavenumber achieved in C-F stretching mode was higher than $\mathrm{C}-\mathrm{Cl}$ due to the presence of the inductive effect between the C-F bond and fluorine, which triggered an increase in the force constant and higher wavenumber absorption [39].

\subsection{Nuclear Magnetic Resonance (NMR) Analysis}

The Nuclear Magnetic Resonance (NMR) of the experimental ${ }^{1} \mathrm{H}$ and ${ }^{13} \mathrm{C}$ was investigated to confirm the total number of hydrogen and carbon atoms present in $\mathbf{C H}-\mathrm{ClF}$ and $\mathrm{CH}-\mathrm{FF}$. In $\mathrm{CH}-\mathrm{ClF}$, the ${ }^{1} \mathrm{H}$ NMR chemical shift values were observed in the range of 8.287-7.389 ppm, whereas the ${ }^{1} \mathrm{H}$ NMR chemical shift values of $\mathbf{C H}-\mathbf{F F}$ were obtained within 8.287-7.123 ppm. The vinylene group $(\mathrm{C}=\mathrm{C})$ hydrogens resonated as two doublets in the ranges of 7.12-7.65 ppm $\left(\mathrm{H}_{\alpha}\right)$ and 7.86-8.29 $\mathrm{ppm}\left(\mathrm{H}_{\beta}\right)$, respectively, which corresponded to the trans double-bond configuration of chalcones [40]. Additionally, the aromatic protons were located in the range of $\delta \mathrm{H} 7.34-7.93 \mathrm{ppm}$ for $\mathrm{CH}-\mathrm{ClF}$ and $\delta$ H 7.41-8.02 ppm CH-FF within the shielded region. The electronic effect of the substituent content in the ring influenced the chemical shift for aromatic photons, which commonly appears between $\delta 6.9$ and $8.0 \mathrm{ppm}$ in either the downfield or the upfield region [40].

The signal observed at $\delta 196.27 \mathrm{ppm}$ and $\delta 198.71 \mathrm{ppm}$ in the ${ }^{13} \mathrm{C}$ NMR spectrum appeared at the most deshielded area, assigned to the C7 atom of the carbonyl group of both $\mathrm{CH}-\mathrm{ClF}$ and $\mathrm{CH}-\mathrm{FF}$. The factor environment and rise of electronegativity from the oxygen atom caused the deshielded area of carbonyl groups compared to other carbon atoms [10]. The chemical shift of aromatic carbons of the phenyl rings was found between 138.5 and $125.0 \mathrm{ppm}$ for both compounds. At the enone bridge, the signals of carbon atoms at the enone moiety for $\mathrm{CH}-\mathrm{ClF}\left(\delta 127.91-129.53 \mathrm{ppm}\left(\mathrm{C}_{\alpha}\right)\right.$ and $\left.\delta 141.23-142.43 \mathrm{ppm}\left(\mathrm{C}_{\beta}\right)\right)$ and CH-FF $\left(\delta 125.63-125.65 \mathrm{ppm}\left(\mathrm{C}_{\alpha}\right)\right.$ and $\left.\delta 142.63-142.65 \mathrm{ppm}\left(\mathrm{C}_{\beta}\right)\right)$ were attained from the ${ }^{13} \mathrm{C}$ NMR spectra.

\subsection{Molecular and Crystal Structural Analysis}

The molecular and optimized structure of the compounds $\mathrm{CH}-\mathrm{ClF}$ and $\mathrm{CH}-\mathrm{FF}$ along with the assigned atom-numbering schema are presented in Figure $4 a, b$, respectively. The new halogen chalcones, namely, (E)-3-(3-chlorophenyl)-1-(4-fluorophenyl)prop-2-en-1-one (CH-ClF) and (E)-3-(3-fluorophenyl)-1-(4-fluorophenyl)prop-2-en-1-one (CH-FF) contained a similar fluoro-substituent unit at the para-position of phenyl ring (R1) and different 
substituents at the meta-position of phenyl ring (R2). Both chalcones represented an acceptor-pi-acceptor (A- $\pi$-A) system [36,40], with the halogen substituents at both ends capped and carbonyls acting as electron-withdrawing groups. Both molecular structures crystallized in a monoclinic crystal system with $P 2_{1}(\mathbf{C H}-\mathbf{C l F})$ and $P 2_{1} / c(\mathbf{C H}-\mathbf{F F})$ space groups. All bond lengths and angles were within the normal ranges [41] and comparable to the previously reported structures of chalcone [42-44]. The geometrical parameters are listed in Table 3 , showing small discrepancies, which reveal that calculation was conducted in the gaseous state while observation was performed in the solution state [45].

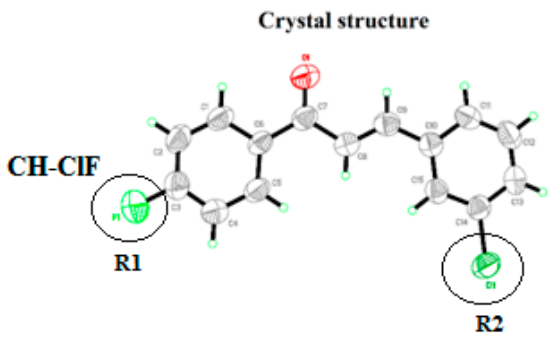

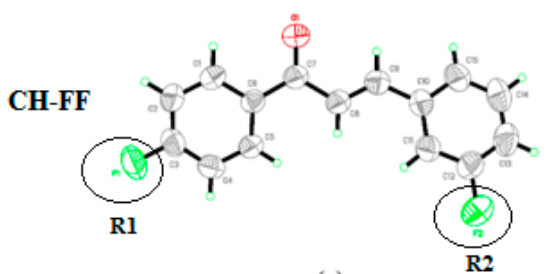

(a)

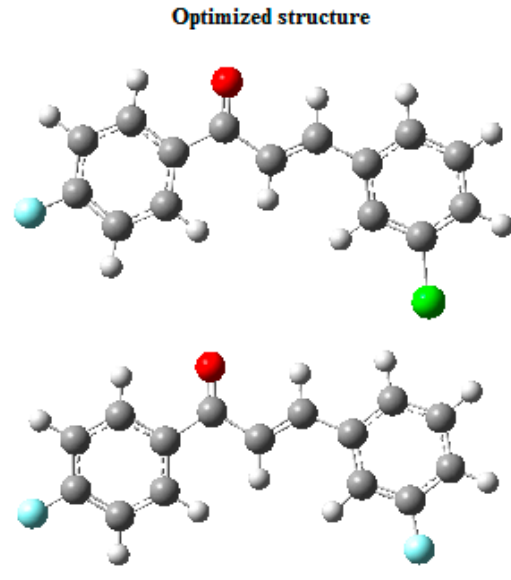

(b)
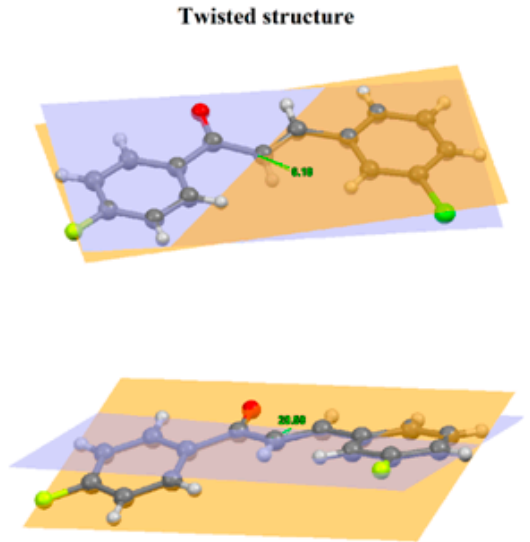

(c)

Figure 4. (a) The molecular structure of the compounds with $50 \%$ ellipsoid probability, with atomic numbering scheme, (b) the optimized structures using DFT/B3LYP/6-311G++(d,p) basis set level, and (c) their respective planarity confirmation.

The molecular structure of both compounds showed an s-cis configuration with respect to the $\mathrm{C} 8=\mathrm{C} 9$ double bond, with bond distances of 1.334 (3) $\AA$ in $\mathrm{CH}-\mathrm{ClF}$ and 1.312 (2) $\AA$ in CH-FF (Table 3). The 4-fluorophenyl moiety (F1/C1-C6) of compound CH-ClF deviated slightly from the $(E)-4$-(3-chlorophenyl) but-3-en-2-one planarity (Cl1/O1/C7C15; maximum deviation: 0.084 (3) $\AA$ at $\mathrm{C} 8$ ) at the $\mathrm{C} 6-\mathrm{C} 7$ bond with the $\mathrm{C} 5-\mathrm{C} 6-\mathrm{C} 7-\mathrm{O} 1$ torsion angle being $-171.2(3)^{\circ}$. Likewise, the fluoro-substituent benzene ring (F1/C1-C6) was slightly twisted at the $\mathrm{C} 6-\mathrm{C} 7$ bond from the mean plane of the (E)-4-(3-fluorophenyl) but -3-en-2-one (F1/O1/C7-C15; maximum deviations: 0.1726 (15) $\AA$ at atom O1) with the $\mathrm{C} 5-\mathrm{C} 6-\mathrm{C} 7-\mathrm{O} 1$ torsion angle value of $173.13(17)^{\circ}$ in compound CH-FF. Interestingly, compound $\mathrm{CH}-\mathrm{ClF}$ was found to be almost planar, with the dihedral angles between the mean plane through the enone moiety (O1/C7-C9; maximum deviation of 0.028 (3) $\AA$ at atom $\mathrm{C} 7$ ) with the fluoro-substituted and chloro-substituted benzene rings (F1/C1-C6 and $\mathrm{Cl1} / \mathrm{C} 10-\mathrm{C} 15)$ were $9.38(18)^{\circ}$ and $6.51(17)^{\circ}$, respectively. Meanwhile, the enone moiety (O1/C7-C9) of compound CH-FF, with a maximum deviation of 0.0295 (16) $\AA$ at atom $\mathrm{C} 7$, formed dihedral angles of $8.33(11)^{\circ}$ and $12.57(11)^{\circ}$ with the fluoro-substituted benzene rings (F1/C1-C6 and F1/C10-C15), respectively. The dihedral and twisted angles further confirmed the non-planar molecular structure of the compound, as shown in Figure 4c. The dihedral angles formed between two C1-C6 (R1) and C10-C15 (R2) phenyl rings for compound $\mathrm{CH}-\mathrm{ClF}$ and $\mathrm{CH}-\mathrm{FF}$ were $6.18^{\circ}$ and $20.58^{\circ}$, respectively. It was found that compound $\mathrm{CH}-\mathrm{FF}$ possessed a large dihedral angle, diminishing the electronic effect between the two phenyl rings through the enone moiety [40]. 
Table 3. Selected bond lengths and angles.

\begin{tabular}{|c|c|c|c|c|}
\hline \multirow[t]{2}{*}{ Compound } & \multicolumn{2}{|c|}{$\mathrm{CH}-\mathrm{ClF}$} & \multicolumn{2}{|c|}{ CH-FF } \\
\hline & Experimental & DFT & Experimental & DFT \\
\hline \multicolumn{5}{|l|}{ Bond length $(\AA)$} \\
\hline C3-F1 & $1.360(3)$ & 1.352 & $1.357(18)$ & 1.352 \\
\hline $\mathrm{C} 7-\mathrm{O} 1$ & $1.212(3)$ & 1.224 & $1.219(17)$ & 1.224 \\
\hline $\mathrm{C} 6-\mathrm{C} 7$ & $1.494(3)$ & 1.501 & $1.484(2)$ & 1.501 \\
\hline $\mathrm{C} 7-\mathrm{C} 8$ & $1.477(3)$ & 1.486 & $1.478(2)$ & 1.486 \\
\hline $\mathrm{C} 8-\mathrm{C} 9$ & $1.334(3)$ & 1.344 & $1.312(2)$ & 1.345 \\
\hline C9-C10 & $1.458(3)$ & 1.463 & $1.458(2)$ & 1.462 \\
\hline $\mathrm{C} 14-\mathrm{Cl1}$ & $1.742(2)$ & 1.759 & - & - \\
\hline $\mathrm{C} 12-\mathrm{F} 2$ & - & - & $1.357(2)$ & 1.355 \\
\hline \multicolumn{5}{|l|}{ Bond angle $\left(^{\circ}\right)$} \\
\hline $\mathrm{O} 1-\mathrm{C} 6-\mathrm{C} 7$ & $120.50(2)$ & 119.85 & $120.26(14)$ & 119.86 \\
\hline $\mathrm{O} 1-\mathrm{C} 7-\mathrm{C} 8$ & $120.90(2)$ & 121.07 & $120.06(14)$ & 121.15 \\
\hline $\mathrm{C} 1-\mathrm{C} 6-\mathrm{C} 7$ & $118.47(19)$ & 117.52 & $118.67(13)$ & 117.58 \\
\hline $\mathrm{C} 5-\mathrm{C} 6-\mathrm{C} 7$ & $123.54(19)$ & 123.83 & $123.19(13)$ & 123.73 \\
\hline $\mathrm{C} 7-\mathrm{C} 8-\mathrm{C} 9$ & $120.60(2)$ & 120.21 & $122.41(14)$ & 120.26 \\
\hline $\mathrm{C} 8-\mathrm{C} 9-\mathrm{C} 10$ & $127.50(2)$ & 127.91 & $128.04(15)$ & 127.82 \\
\hline $\mathrm{C} 9-\mathrm{C} 10-\mathrm{C} 11$ & $119.00(2)$ & 118.63 & $122.19(14)$ & 122.92 \\
\hline $\mathrm{C} 9-\mathrm{C} 10-\mathrm{C} 15$ & $122.28(19)$ & 122.90 & $119.89(15)$ & 118.60 \\
\hline \multicolumn{5}{|l|}{ Torsion angle $\left({ }^{\circ}\right)$} \\
\hline $\mathrm{C} 1-\mathrm{C} 6-\mathrm{C} 7-\mathrm{O} 1$ & $7.3(4)$ & 9.2 & $-6.0(3)$ & -11.2 \\
\hline $\mathrm{C} 5-\mathrm{C} 6-\mathrm{C} 7-\mathrm{O} 1$ & $-171.2(3)$ & 10.8 & $173.13(17)$ & 167.61 \\
\hline $\mathrm{O} 1-\mathrm{C} 7-\mathrm{C} 8-\mathrm{C} 9$ & $6.9(4)$ & 3.3 & $-7.5(3)$ & -4.2 \\
\hline $\mathrm{C} 6-\mathrm{C} 7-\mathrm{C} 8-\mathrm{C} 9$ & $-173.8(2)$ & -177.4 & $172.78(16)$ & 176.68 \\
\hline $\mathrm{C} 7-\mathrm{C} 8-\mathrm{C} 9-\mathrm{C} 10$ & $-179.5(2)$ & -179.3 & $-179.33(16)$ & 179.03 \\
\hline $\mathrm{C} 8-\mathrm{C} 9-\mathrm{C} 10-\mathrm{C} 11$ & $170.5(2)$ & -179.7 & $-8.9(3)$ & -1.6 \\
\hline $\mathrm{C} 8-\mathrm{C} 9-\mathrm{C} 10-\mathrm{C} 15$ & $-9.5(4)$ & 0.3 & $171.66(18)$ & 178.47 \\
\hline
\end{tabular}

In the crystal packing of the compound CH-FF (Figure 5b), the molecules were connected by intermolecular $\mathrm{C} 2-\mathrm{H} 2 A \cdots \mathrm{O} 1$ (symmetry code: $-x+1, y+1 / 2,-z+3 / 2$ ) and C13-H13A ․ F1 (symmetry code: $-x,-y-1 / 2, z-1 / 2$ ) hydrogen bonds (Table 4 ) to form an infinite two-dimensional sheet parallel along the ac-plane. This parallel sheet was further linked to the neighboring sheet by intermolecular $\mathrm{C} 2-\mathrm{H} 2 A \cdots \mathrm{O} 1$ hydrogen bonds propagating along the $b$-axis direction. In addition, the intermolecular $\mathrm{C}-\mathrm{H} \cdots \mathrm{O}$ and $\mathrm{C}-\mathrm{H} \cdots \mathrm{Fl}$ hydrogen bonds led to the formation of $R_{4}^{4}(26)$ ring motifs [46]. Notably, there were no classical hydrogen bonding interactions found in compound $\mathrm{CH}-\mathrm{ClF}$ (Figure 5a).

\subsection{Hirshfeld Surface Calculations}

The presence of intermolecular interactions in the compound were verified by performing the Hirshfeld surface analysis. This provided a three-dimensional visual understanding of the intermolecular contacts and crystal packing of a compound under different types of surface properties and displayed the quantitative statistical distribution of specific interactions. The normalized contact distance $d_{n o r m}$ and the breakdown of the associated fingerprint plots of the compounds are depicted in Figures 6 and 7, respectively. The compound CH-FF is depicted as bright red spots on the Hirshfeld surface mapped over $d_{\text {norm }}$, indicating the presence of $\mathrm{C} 2-\mathrm{H} 2 \mathrm{~A} \cdots \mathrm{O} 1$ and $\mathrm{C} 13-\mathrm{H} 13 \mathrm{~A} \cdots \mathrm{F} 1$ intermolecular interactions connected with neighboring molecules with a distance of $2.58 \AA$ and $2.55 \AA$, respectively. However, no bright red spots were observed in compound $\mathrm{CH}-\mathrm{ClF}$, signifying that intermolecular interactions were not involved in the molecule. Meanwhile, the blue and white regions represent longer intermolecular contacts and contacts around the Van der Waals separation, respectively. The 2D fingerprint plots were deconstructed to highlight particular atom pair contacts in both molecules, delineated into $\mathrm{H} \cdots \mathrm{H}, \mathrm{C} \cdots \mathrm{H} / \mathrm{H} \cdots \mathrm{C}$, $\mathrm{O} \cdots \mathrm{H} / \mathrm{H} \cdots \mathrm{O}, \mathrm{F} \cdots \mathrm{H} / \mathrm{H} \cdots \mathrm{F}, \mathrm{C} \cdots \mathrm{C}, \mathrm{Cl} \cdots \mathrm{H} / \mathrm{H} \cdots \mathrm{Cl}$ and $\mathrm{C} \cdots \mathrm{F} / \mathrm{F} \cdots \mathrm{C}$. The Hirshfeld surface analysis of both compounds showed $\mathrm{H} \cdots \mathrm{H}$ interactions of $28 \%(\mathbf{C H}-\mathrm{ClF})$ and $33 \%$ (CH-FF), which were thus revealed as the major contributor to intermolecular interactions 
and are represented by the largest region in the fingerprint plot ( Figure 7). Meanwhile, the second largest contributor in the compound $\mathbf{C H}-\mathrm{ClF}$ were $\mathrm{C} \cdots \mathrm{H} / \mathrm{H} \cdots \mathrm{C}$ contacts, with $15.8 \%$, whereas $\mathrm{F} \cdots \mathrm{H} / \mathrm{H} \cdots \mathrm{F}$ in compound $\mathrm{CH}-\mathrm{FF}$ was the second largest ranking contribution with $26.2 \%$, depicted by two narrow sharp spikes attributed to the presence of intermolecular $\mathrm{C} 13-\mathrm{H} 13 \mathrm{~A} \cdots \mathrm{F} 1$ interactions. In addition, the $\mathrm{O} \cdots \mathrm{H} / \mathrm{H} \cdots \mathrm{O}$ contact became the inferior contributor in compound $\mathrm{CH}-\mathrm{ClF}$ and fourth ranking contribution in compound $\mathbf{C H}-\mathbf{F F}$, with $8.3 \%$ and $10.2 \%$, respectively, as observed by two symmetrical narrow spikes with $d_{i}+d_{e} \sim 2.4 \AA$ where this value was approximately closer to the separation distance of the hydrogen bond interaction between the hydrogen atom and oxygen of the carbonyl group (H2A … O1).
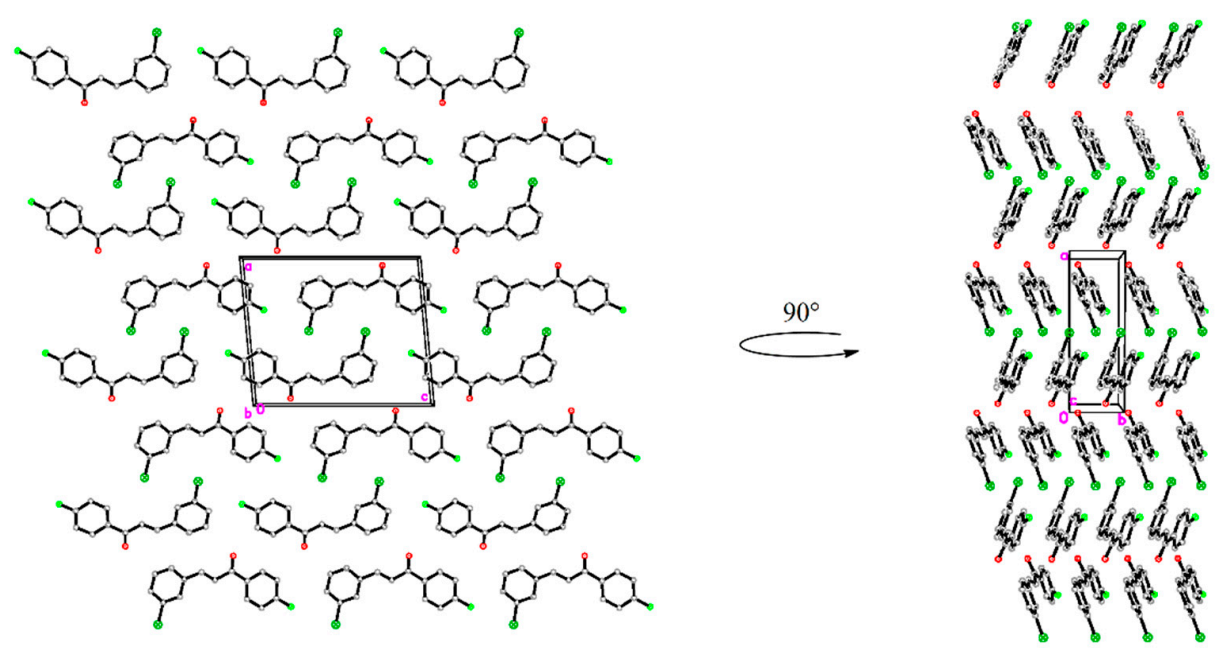

(a)
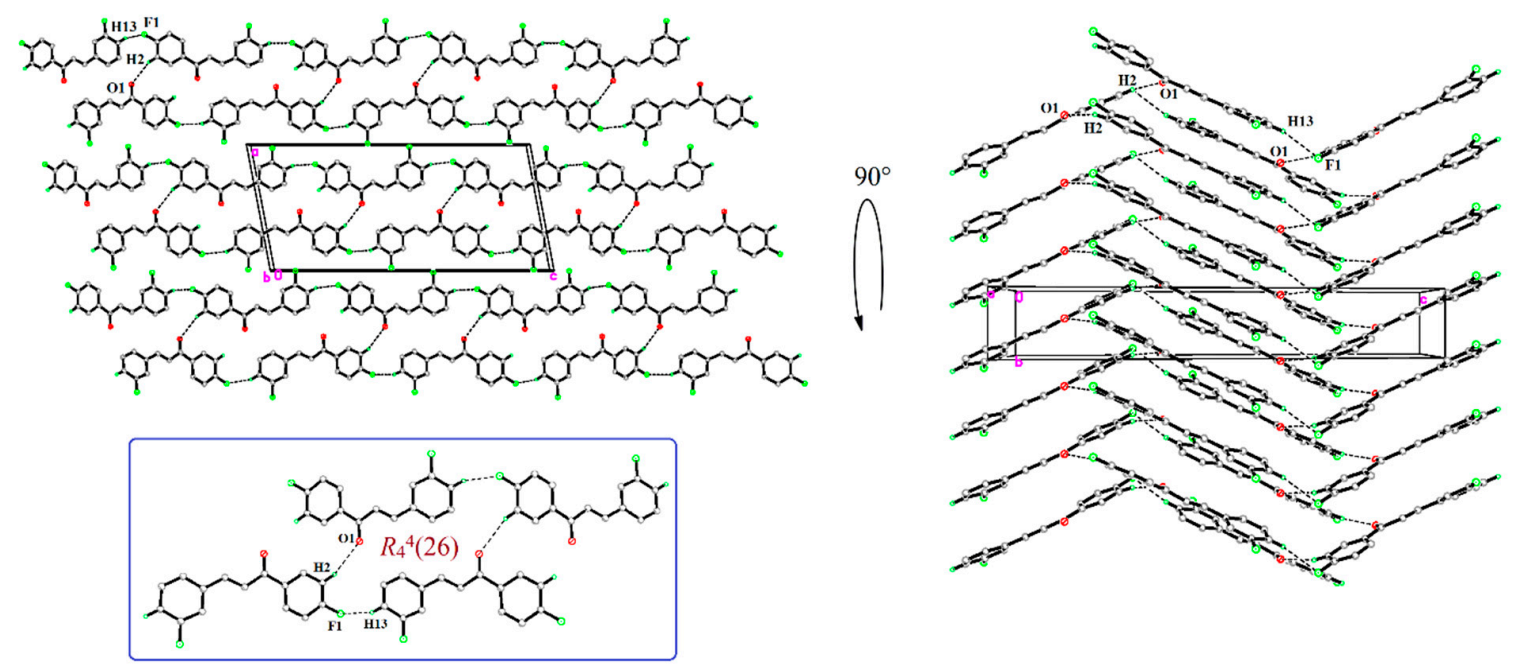

(b)

Figure 5. Crystal packing of compound (a) $\mathrm{CH}-\mathrm{ClF}$ and (b) $\mathrm{CH}-\mathrm{FF}$ showing that the molecules are connected by intermolecular $\mathrm{C}-\mathrm{H} \cdots \mathrm{O}$ and $\mathrm{C}-\mathrm{H} \cdots \mathrm{F}$ hydrogen bonds into a two-dimensional sheet parallel to the $a c$-plane. The observed $\mathrm{C}-\mathrm{H} \cdots \mathrm{O}$ bond propagates along the $b$-axis direction. 
Table 4. Hydrogen bond geometry $\left(\AA,^{\circ}\right)$.

\begin{tabular}{cccccc}
\hline \multirow{2}{*}{ Compound } & $\begin{array}{c}\text { Bond } \\
\text { D-H } \cdots \mathbf{A}\end{array}$ & D-H & $\begin{array}{c}\text { Bond Length, }(\AA) \\
\mathbf{H} \cdots \mathbf{A}\end{array}$ & $\mathbf{D} \cdots \mathbf{A}$ & $\begin{array}{c}\text { Angle } \\
\mathbf{D}-\mathbf{H} \cdots \mathbf{A}\left({ }^{\circ}\right)\end{array}$ \\
\hline \multirow{2}{*}{ CH-FF } & $\mathrm{C} 2-\mathrm{H} 2 \mathrm{~A} \cdots \mathrm{O} 1^{(\mathrm{i})}$ & 0.93 & 2.58 & $3.464(2)$ & 158 \\
& $\mathrm{C} 13-\mathrm{H} 13 \mathrm{~A} \cdots \mathrm{F}{ }^{(\mathrm{ii})}$ & 0.93 & 2.55 & $3.422(2)$ & 157 \\
\hline
\end{tabular}

Symmetry codes: (i) $-x+1, y+1 / 2,-z+3 / 2$; (ii) $-x,-y-1 / 2, z-1 / 2$.

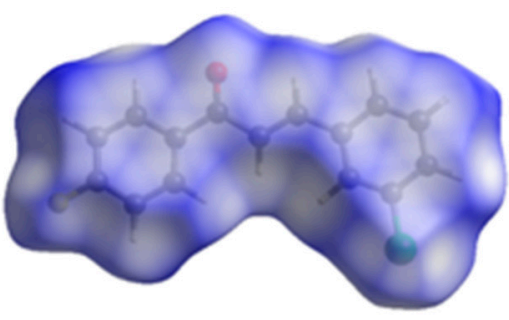

CH-ClF

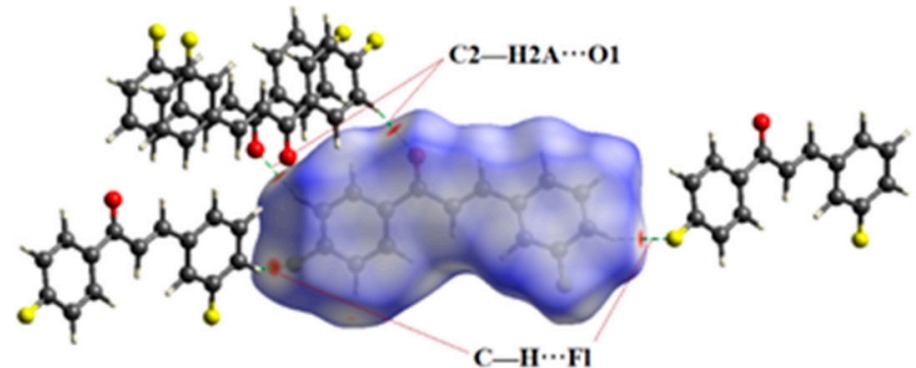

CH-FF

Figure 6. $d_{\text {norm }}$ surface.

\subsection{Ultraviolet-Visible (UV-Vis) and Frontier Molecular Orbital (FMO) Analysis}

The important parameters for studying the reactivity of the molecules were analyzed using HOMO and LUMO energies, with HOMO playing a crucial part in illustrating the capability of the compounds as electron donors to unoccupied molecular orbitals [9]. The electronic transition between HOMO and LUMO of $\mathbf{C H}-\mathrm{ClF}$ and $\mathbf{C H}-\mathrm{FF}$ showed a similar trend movement, as can be seen in Figure 8. The electron distributions in the HOMO state were localized at the ethylenic bridge and phenyl ring attached to the chlorine and fluorine atom of $\mathrm{CH}-\mathrm{ClF}$ and $\mathrm{CH}-\mathrm{FF}$, respectively. Additionally, both compounds had a small molecular orbital localization at the phenyl ring that bonded to the fluorine atom of each molecule. In the LUMO state, the electron distributions were firmly distributed through the molecular skeleton of both compounds. The energy shift of frontier orbitals from HOMO to LUMO was calibrated by using TD-DFT/B3LYP in order to identify the theoretical absorption maximum values for compounds $\mathrm{CH}-\mathrm{ClF}$ and $\mathrm{CH}-\mathrm{FF}$, which were $336.39 \mathrm{~nm}$ and $363.69 \mathrm{eV}$, respectively.

In the working principle of DSSC, an appropriate energy level is required for deployment as a sensitizer to ensure the occurrence of the electron injection and dye regeneration processes [47]. Figure 8 represents the HOMO energy levels of both compounds, which were lower than the redox potential of $\mathrm{I}^{-} / \mathrm{I}_{3}^{-}(-4.8 \mathrm{eV})$, indicating the ability of the oxidized dye to be restored by obtaining electrons from the electrolyte [10]. Likewise, the higher LUMO energy levels compared to the $\mathrm{TiO}_{2}$ conduction band energy level $(-4.0 \mathrm{eV})$ of $\mathrm{CH}-\mathrm{ClF}$ and $\mathrm{CH}-\mathrm{FF}$ suggested the presence of electron injection from the dye to the semiconductor substrate [10]. Hence, the HOMO and LUMO energy levels in Figure 8 illustrate the potential of the $\mathbf{C H}-\mathrm{ClF}$ and $\mathbf{C H}-\mathbf{F F}$ compounds as dye-sensitizers in DSSC applications.

Meanwhile, the UV-vis absorption spectrum in Figure 9 was conducted in an acetonitrile solution $\left(10^{-5} \mathrm{M}\right)$ with a cutoff wavelength of $190 \mathrm{~nm}$. The energy gap values of CH-ClF (experimental: $4.44 \mathrm{eV}$; theoretical: $4.17 \mathrm{eV}$ ) and CH-FF (experimental: $4.38 \mathrm{eV}$; theoretical: $4.10 \mathrm{eV}$ ) were successfully attained. The isolated condition while conducting the theoretical calculations resulted in a slight deviation from the experimental value. The absorption spectra of $\mathbf{C H}-\mathrm{ClF}$ and $\mathrm{CH}-\mathrm{FF}$ depicted similar wavelength regions to previously reported compounds containing fluorine substituents $[48,49]$. Wavelength absorption is influenced by the electron affinity properties of the reported compounds [48]. 

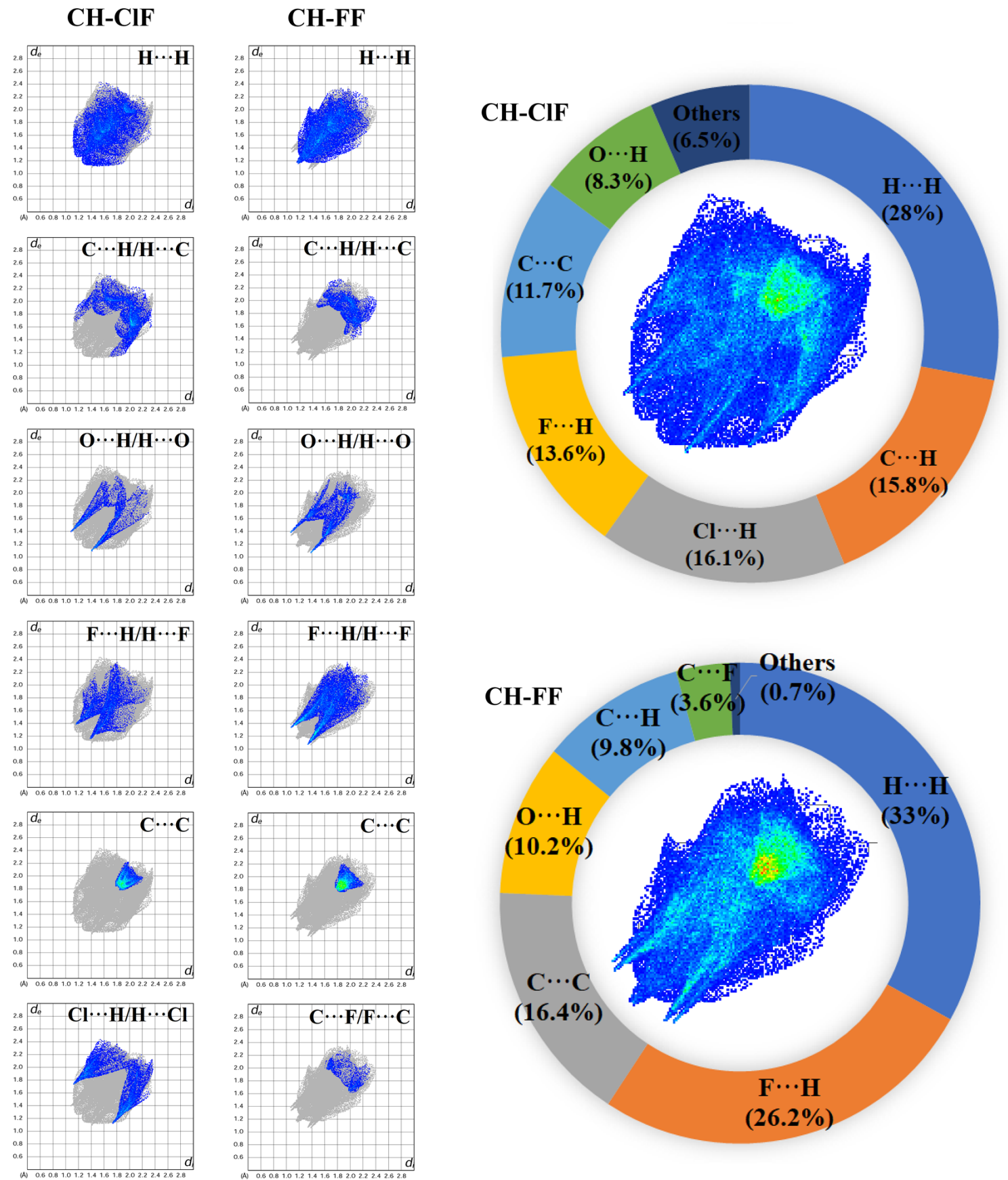

Figure 7. Fingerprint plots of intermolecular contacts showing the percentage contributions to the total Hirshfeld surface area. 


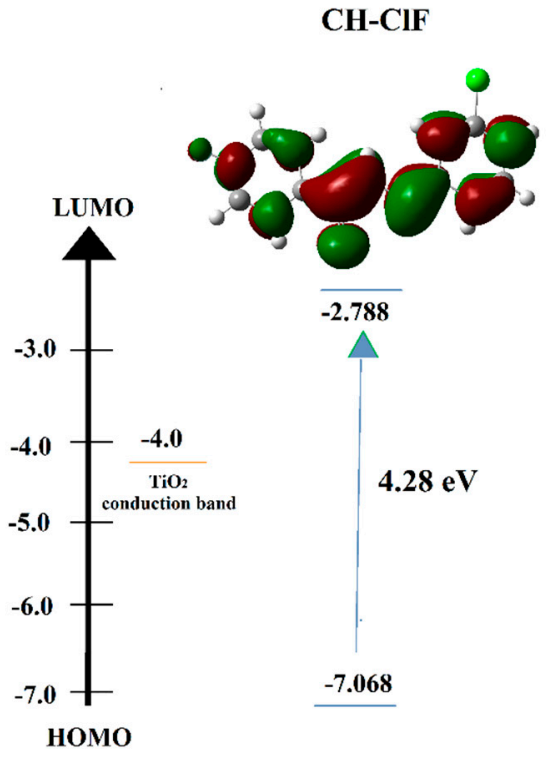

CH-FF
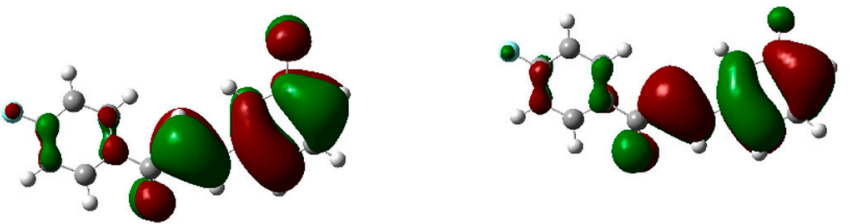

Figure 8. Molecular orbitals of the HOMO-LUMO energy levels of both compounds.

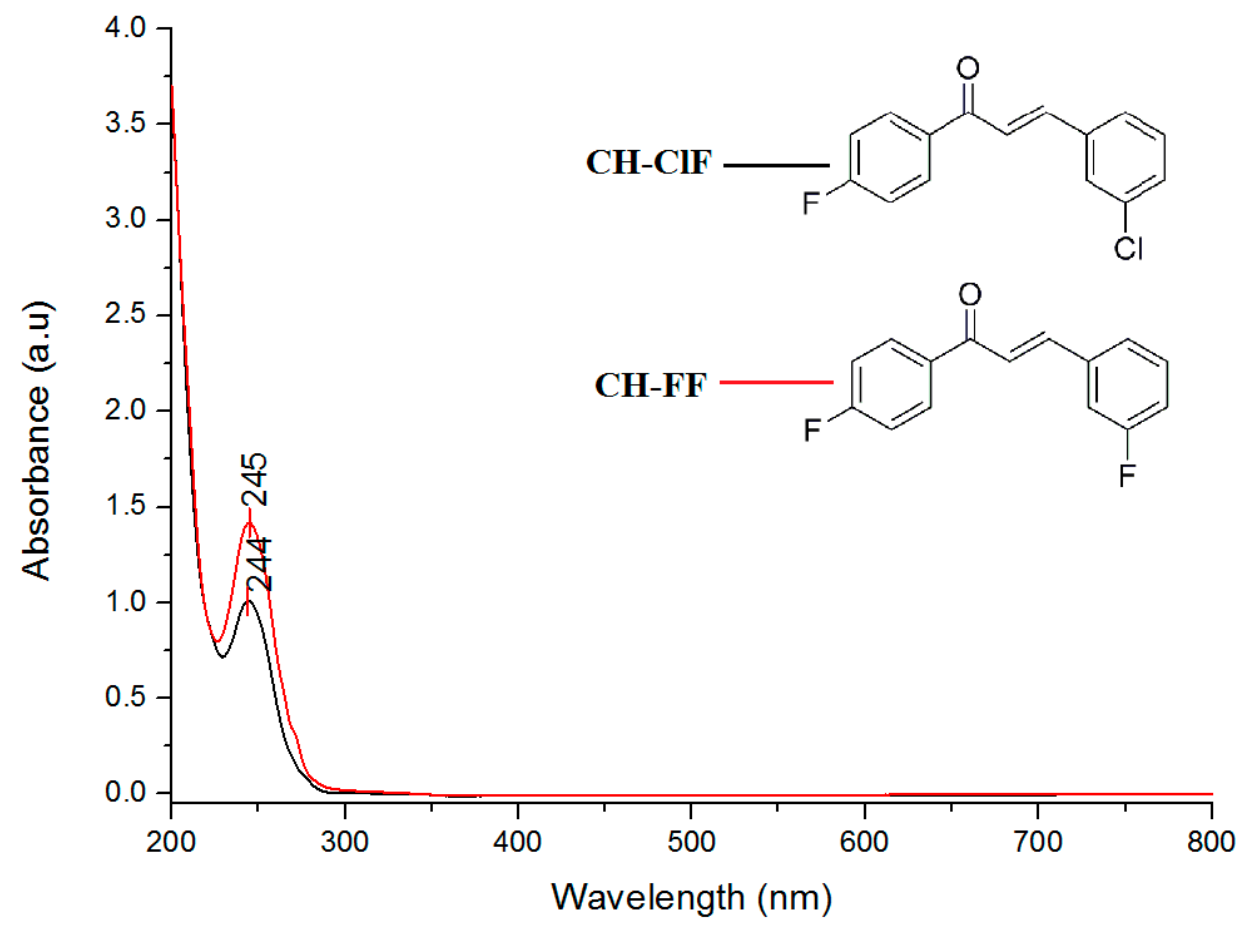

Figure 9. The experimental UV-vis spectra of $\mathrm{CH}-\mathrm{ClF}$ and $\mathrm{CH}-\mathrm{FF}$.

\subsection{DSSC Applications and Performance}

The photovoltaic performance of DSSC was associated with essential parameters, which were short circuit current $\left(\mathrm{J}_{\mathrm{sc}}\right)$, open circuit voltage $\left(\mathrm{V}_{\mathrm{oc}}\right)$, fill factor $(\mathrm{FF})$ and power efficiency $(\eta)$, as defined in Table 5 and illustrated in the $J-V$ characteristic curve in Figure 10 for the reported compounds, N719, and the DSSC without sensitizer. The $\mathrm{J}_{\mathrm{Sc}}$ was controlled by the ability of dye molecules to absorb light and the flow of charge through the dye 
molecules to the nanocrystalline $\mathrm{TiO}_{2}$ area [10]. The Fill Factor (FF) operated on the quality of the device's performance, which was influenced by appropriate $\mathrm{TiO}_{2}$ thickness, suitable electrolyte solution, and photocurrent conversion by the dye-sensitizer [50]. The ability of the dye to be coated well on the $\mathrm{TiO}_{2}$ surface during the fabrication process was important in achieving better DSSC efficiency.

Table 5. Photovoltaic parameters summary of the DSSCs performance.

\begin{tabular}{ccccc}
\hline Compound & $\begin{array}{c}\text { Current } \\
\text { Density, } \\
\mathbf{J}_{\mathbf{s c}}\left(\mathbf{m} / \mathbf{c m}^{\mathbf{2}}\right)\end{array}$ & $\begin{array}{c}\text { Open Circuit } \\
\text { Voltage, V } \\
\mathbf{( m V )}\end{array}$ & $\begin{array}{c}\text { Fill Factor, } \\
\text { FF (\%) }\end{array}$ & $\begin{array}{c}\text { Efficiency, } \boldsymbol{\eta} \\
\mathbf{( \% )}\end{array}$ \\
\hline CH-CIF & 0.024 & 492 & 70.2 & 0.00832 \\
\hline CH-FF & 0.086 & 580 & 72.8 & 0.03632 \\
\hline N719 & 0.589 & 609 & 73.8 & 0.26470 \\
\hline No Sensitizer & 0.002 & 54 & 23.9 & 0.00002 \\
\hline
\end{tabular}

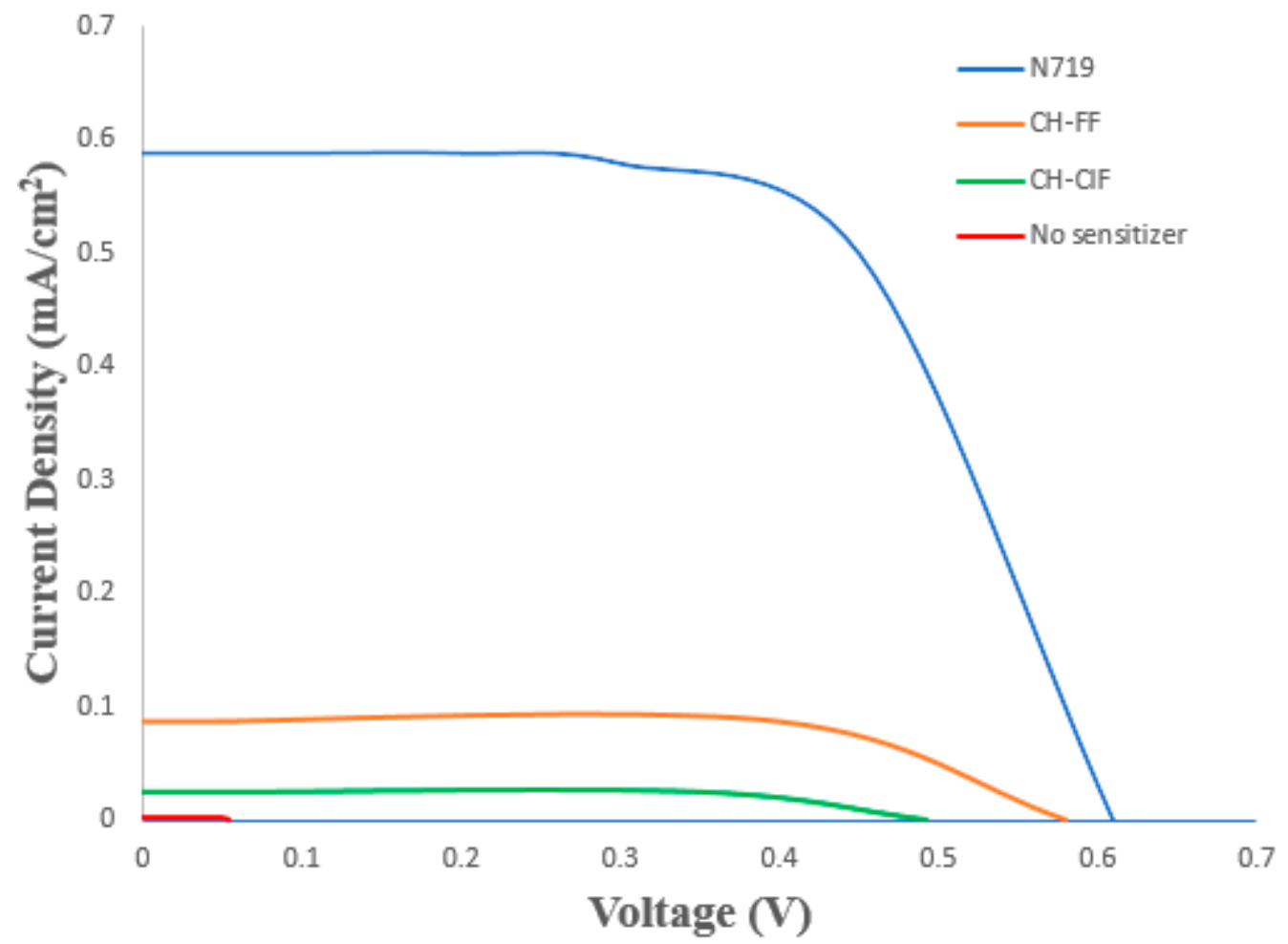

Figure 10. J-V curves for DSSCs of the reported compounds under irradiance.

In this research, the halogenated chalcone cells were tested along with the standard dye (N719) and the cell without sensitizer under the same conditions for comparison and consistency. As can be seen in Figure 10, all plotted curves displayed an almost similar trend with the increment of $\mathrm{J}_{\mathrm{sc}}$, which caused the $\mathrm{V}_{\mathrm{oc}}$ to be gradually shifted to the right. The graph shows higher current density for the N719 than the halogenated chalcones tested. Meanwhile, the DSSC without any sensitizer shows the smallest $\mathrm{J}_{\mathrm{sc}}$ value $\left(0.002 \mathrm{~mA} / \mathrm{cm}^{2}\right)$ in the $\mathrm{TiO}_{2}$ layer, suggesting the presence of $\mathrm{CH}-\mathrm{ClF}$ and $\mathrm{CH}-\mathrm{FF}$ as potential sensitizers to compliment the photovoltaic performance. Furthermore, these results support the fact that the fluorinated chalcones were anchored on the $\mathrm{TiO}_{2}$ layer.

From Table 5, the open circuit voltages $\left(\mathrm{V}_{\mathrm{oc}}\right)$ achieved by $\mathrm{CH}-\mathrm{ClF}$ and $\mathrm{CH}-\mathrm{FF}$ were higher than the DSSC without sensitizer; however, they were lower than the standard dye, N719. The $V_{\text {oc }}$ results were controlled by the concentration of injected electrons at the $\mathrm{TiO}_{2}$ layer and the electron recombination process that occurred between the dye 
molecules and the electrolyte [10]. The higher values of $\mathrm{V}_{\mathrm{oc}}$ were due to efficient electron injection accumulation at the $\mathrm{TiO}_{2}$ and a low injected electron recombination rate with the electrolyte [51].

The efficiency of the DSSC performance for both halogenated chalcone, N719, and the cell without sensitizer were calculated using Equation (2). The results revealed that the DSSC conversion efficiency of $\mathbf{C H}-\mathbf{F F}(\eta=0.03632 \%)$ was larger than $\mathbf{C H}-\mathbf{C l F}$ $(\eta=0.00832 \%)$ due to the structural configuration of $\mathbf{C H}-\mathbf{F F}$ with -fluoro attachments on both aromatic rings, leading to the higher electronegativity properties compared to $\mathbf{C H}-\mathbf{C l F}$. The electronegativity properties acted as the chemical descriptor for the atoms within the compound to attract the electrons during the chemical reaction [19]. Hence, this led to the good quality of charge transfer within the $\mathbf{C H}-\mathbf{F F}$ molecules, which also affected the HOMO-LUMO energy levels for an excellent band energy [20,21]. The flow of charge transfer within HOMO-LUMO energy levels is important to ease the electron injection process in the $\mathrm{TiO}_{2}$ layer [10]. These criteria were well defined for $\mathbf{C H}-\mathbf{F F}$, resulting in a higher $\mathrm{J}_{\mathrm{sc}}$ values ( Figure 10) and DSSC conversion efficiency.

$$
\eta=\frac{J_{s c} \times V_{o c} \times F F}{P_{i n}}
$$

Additionally, $\mathbf{C H}-\mathrm{FF}$ molecules were stabilized by the various hydrogen bond interactions of $\mathrm{C}-\mathrm{H} \cdots \mathrm{O}$ and $\mathrm{C}-\mathrm{H} \cdots \mathrm{F}$. The existence of intermolecular interactions in DSSC induced the charge transfer between the molecules to facilitate the electron injection and dye regeneration process for better photovoltaic performance. In addition, the high percentage of Fill Factor (FF) indicated the possibility of high-energy conversion and good dye absorption in the $\mathrm{TiO}_{2}$ area [13]. The fill factor, FF achieved by CH-FF (72.8\%) in Table 5 shows its better fabrication and good absorption process compared to $\mathbf{C H}-\mathbf{C l F}$ (70.2\%). However, the efficiency of $\mathbf{C H - C l F}$ and $\mathbf{C H}-\mathbf{F F}$, as shown in Figure 10, were lower than the standard dye. This is due to the $-\mathrm{COOH}$ functional group that exists in N719, which helps to facilitate electron transport compared to the reported compounds without a $-\mathrm{COOH}$ anchoring group. The presence of the $-\mathrm{COOH}$ attachment was reported as a good potential factor for the dye to anchor on the $\mathrm{TiO}_{2}$ area by improving the coupling effect of electrons [15]. The DSSC efficiency achieved by $\mathbf{C H}-\mathbf{C l F}$ was comparable with the previously reported studies [52]; however, CH-FF shows lower power conversion results.

\section{Conclusions}

In the final analysis, we have discovered that the efficiencies of the DSSC application contributed well to the electronegativity of the designed compounds. The compound with the highest electronegative properties (CH-FF) was able to enhance the charge transfer flow inside the molecules compared to the compound with lower electronegativity $(\mathbf{C H}-\mathbf{C l F})$. The charge movement within the molecules was clearly shown in the energy shift of the frontier orbitals from HOMO to LUMO, as calibrated at $4.28 \mathrm{eV}(\mathbf{C H}-\mathbf{C l F})$ and $4.10 \mathrm{eV}$ (CH-FF). Apart from this, the strong intermolecular interactions helped to further stabilize the compound, resulting in better performance of the DSSC due to excellent charge mobility between the molecules. $\mathbf{C H}-\mathrm{FF}$ possessed $\mathrm{C}-\mathrm{H} \cdots \mathrm{O}$ and $\mathrm{C}-\mathrm{H} \cdots \mathrm{F}$ interactions, while there were no classical hydrogen bonding interactions found in $\mathbf{C H}-\mathbf{C l F}$, as confirmed by the Hirshfeld analysis. This successfully yielded a DSSC conversion power for $\mathbf{C H}-\mathbf{F F}$ and CH-ClF of $0.03632 \%$ and $0.00832 \%$, respectively.

Supplementary Materials: The following are available online at https://www.mdpi.com/article/10.339 0/cryst11111357/s1, Figure S1: (a) The image of the sensitized $\mathrm{TiO}_{2}$ on the working electrode before fabrication and (b) after fabrication with electrolyte injected on the $\mathbf{C H}-\mathbf{C l F}$ and $\mathbf{C H}-\mathbf{F F}$ cells. 
Author Contributions: Conceptualization, S.N.A.M.N., S.N.F.A.R., M.F.Z. and A.H.A.; Methodology, S.N.A.M.N., S.N.F.A.R., M.F.Z. and A.H.A.; Funding acquisition, S.A.; Project administration: S.A. and I.A.R.; Supervision, S.A. and I.A.R.; Visualization, S.N.A.M.N., S.N.F.A.R., M.F.Z. and A.H.A., Writing—original draft: S.N.A.M.N., S.N.F.A.R., M.F.Z., A.H.A. and S.A.; Writing一review \& editing: S.N.A.M.N., M.F.Z., A.H.A. and S.A. All authors have read and agreed to the published version of the manuscript.

Funding: This work was funded under the Research University Grant (RUI) No. 1001.PFIZIK.8011115.

Institutional Review Board Statement: Not applicable.

Informed Consent Statement: Not applicable.

Data Availability Statement: CCDC 1521381 and 1521383 contain the supplementary crystallographic data for this paper. These data can be obtained free of charge via www.ccdc.cam.ac.uk/ data_request/cif, or by emailing data_request@ccdc.cam.ac.uk, or by contacting The Cambridge Crystallographic Data Centre, 12 Union Road, Cambridge CB2 1EZ, UK; fax: +44 1223336033.

Acknowledgments: The authors would like to thank the Malaysian Government and Universiti Sains Malaysia for providing facilities and funding to conduct this work.

Conflicts of Interest: The authors declare no conflict of interest.

\section{References}

1. Prabhu, A.N.; Upadhyaya, V.; Jayarama, A.; Bhat, K.S. Synthesis, growth and characterization of $\pi$ conjugated organic nonlinear optical chalcone derivative. Mater. Chem. Phys. 2013, 138, 179-185. [CrossRef]

2. Shehzad, R.A.; Muhammad, S.; Chaudhry, A.R.; Ito, S.; Iqbal, J.; Khalid, M.; Aloui, Z.; Xu, H.-L. Electro-Optical and Charge Transport Properties of Chalcone Derivatives Using a Dual Approach from Molecule to Material Level Simulations. Comput. Theor. Chem. 2021, 1203, 113349. [CrossRef]

3. Alidmat, M.M.; Khairuddean, M.; Norman, N.M.; Asri, A.N.M.; Suhaimi, M.H.M.; Sharma, G. Synthesis, Characterization, Docking Study and Biological Evaluation of New Chalcone, Pyrazoline, and Pyrimidine Derivatives as Potent Antimalarial Compounds. Arab. J. Chem. 2021, 14, 103304. [CrossRef]

4. Wu, X.; Shi, Y.; Ju, Y.; Jia, J.; Fang, Y.; Chen, Y.; Wu, Q.; Song, Y. Investigation of the intensity dependent transition from saturable absorption to reverse saturable absorption and ultrafast negative refraction in terthiophene-based chalcone derivatives. Opt. Mater. 2021, 117, 111174. [CrossRef]

5. Gomes, L.R.; Low, J.N.; Wardell, J.L. Crystal structures, Hirshfeld surface analysis and PIXEL calculations of two chalcone derivatives, containing isopropoxy substituents: Importance of dispersion energy. J. Mol. Struct. 2021, 1237, 130354. [CrossRef]

6. Kiran, M.S.; Anand, B.; Sankara, S.S.; Rao, G.N. Second- and third-order nonlinear optical properties of bis-chalcone derivatives. J. Photochem. Photobiol. A Chem. 2014, 290, 38-42. [CrossRef]

7. Vlasiou, M.C.; Al Hatahta, A. Spectroscopic evaluation of chalcone derivatives and their zinc metal complexes: A combined experimental and computational approach studying the interactions of the complexes with the serum albumin. J. Mol. Struct. 2021, 1232, 130052. [CrossRef]

8. Makhlouf, M.M.; Radwan, A.S.; Ghazal, B. Experimental and DFT insights into molecular structure and optical properties of new chalcones as promising photosensitizers towards solar cell applications. Appl. Surf. Sci. 2018, 452, 337-351. [CrossRef]

9. Anizaim, A.H.; Zainuri, D.A.; Zaini, M.F.; Razak, I.A.; Bakhtiar, H.; Arshad, S. Comparative analyses of new donor- $\pi$-acceptor ferrocenyl-chalcones containing fluoro and methoxy-fluoro acceptor units as synthesized dyes for organic solar cell material. PLoS ONE 2020, 15, e0241113. [CrossRef]

10. Anizaim, A.H.; Zaini, M.F.; Razak, I.A.; Arshad, S. Insight into the impact of the substituent modification on the photovoltaic performance of ferrocenyl chalcones based DSSCs. J. Solid State Chem. 2021, 304, 122551. [CrossRef]

11. Phan, T.P.; Teo, K.Y.; Liu, Z.Q.; Tsai, J.K.; Tay, M.G. Application of unsymmetrical bis-chalcone compounds in dye sensitized solar cell. Chem. Data Collect. 2019, 22, 100256. [CrossRef]

12. Rajakumar, P.; Thirunarayanan, A.; Raja, S.; Ganesan, S.; Maruthamuthu, P. Photophysical properties and dye-sensitized solar cell studies on thiadiazole-triazole-chalcone dendrimers. Tetrahedron Lett. 2012, 53, 1139-1143. [CrossRef]

13. Rajakumar, P.; Kalpana, V.; Ganesan, S.; Maruthamuthu, P. Synthesis and DSSC application of novel dendrimers with benzothiazole and triazole units. Tetrahedron Lett. 2011, 52, 5812-5816. [CrossRef]

14. Rajakumar, P.; Visalakshi, K.; Ganesan, S.; Maruthamuthu, P.; Suthanthiraraj, S.A. Pyreno-chalcone dendrimers as an additive in the redox couple of dye-sensitized solar cells. J. Mater. Sci. 2012, 47, 1811-1818. [CrossRef]

15. Chauhan, R.; Yadav, R.; Singh, A.K.; Trivedi, M.; Kociok-Köhn, G.; Kumar, A.; Gosavi, S.; Rane, S. Ferrocenyl chalcones with phenolic and pyridyl anchors as potential sensitizers in dye-sensitized solar cells. RSC Adv. 2016, 6, 97664-97675. [CrossRef]

16. Omar, A.; Ali, M.S.; Rahim, N.A. Electron transport properties analysis of titanium dioxide dye-sensitized solar cells (TiO2-DSSCs) based natural dyes using electrochemical impedance spectroscopy concept: A review. Sol. Energy 2020, 207, 1088-1121. [CrossRef] 
17. Yahya, M.; Bouziani, A.; Ocak, C.; Seferoğlu, Z.; Sillanpää, M. Organic/metal-organic photosensitizers for dye-sensitized solar cells (DSSC): Recent developments, new trends, and future perceptions. Dye. Pigment. 2021, 192, 109227. [CrossRef]

18. Patil, S.S.; Mane, R.M.; Khot, K.V.; Mali, S.S.; Hong, C.K.; Bhosale, P.N. Surfactant assisted approach to development of efficient WO3 photoanode for natural dye sensitized solar cell. Sol. Energy 2021, 220, 371-383. [CrossRef]

19. Dimitrov, V.; Komatsu, T. Correlation among electronegativity, cation polarizability, optical basicity and single bond strength of simple oxides. J. Solid State Chem. 2012, 196, 574-578. [CrossRef]

20. Mujica-Martínez, C.A.; Arce, J.C. Mini-bandstructure tailoring in pi-conjugated periodic block copolymers using the envelope crystalline-orbital method. Int. J. Quantum Chem. J. 2010, 110, 2532-2540.

21. Pan, S.; Kong, X.; Zhang, Q.; Xu, Q.; Wang, M.; Wei, C.; Zhao, Y.; Zhang, X. Rational modulating electronegativity of substituents in amorphous metal-organic frameworks for water oxidation catalysis. Int. J. Hydrogen Energy 2020, 45, 9723-9732. [CrossRef]

22. Zhang, B.; Chou, L.; Bi, Y. Tuning surface electronegativity of BiVO4 photoanodes toward high-performance water splitting. Appl. Catal. B Environ. 2020, 262, 118267. [CrossRef]

23. Bruker, A. Saint and SADABS; Bruker AXS Inc.: Madison, WI, USA, 2009.

24. Sheldrick, G. A short history of SHELX. Acta Crystallogr. Sect. A 2008, 64, 112-122. [CrossRef] [PubMed]

25. Spek, A.L. Structure validation in chemical crystallography. Acta Crystallogr. Sect. D Biol. Crystallogr. 2009, 65, 148-155. [CrossRef] [PubMed]

26. Macrae, C.F.; Bruno, I.; Chisholm, J.A.; Edgington, P.R.; McCabe, P.; Pidcock, E.; Rodriguez-Monge, L.; Taylor, R.J.; van de Streek, J.; Wood, P. Mercury CSD 2.0- new features for the visualization and investigation of crystal structures. J. Appl. Crystallogr. 2008, 41, 466-470. [CrossRef]

27. Wolff, S.; Grimwood, D.; McKinnon, J.; Turner, M.; Jayatilaka, D.; Spackman, M. Crystal Explorer; The University of Western Australia: Perth, Australia, 2012.

28. Ternavisk, R.R.; Camargo, A.J.; Machado, F.B.C.; Rocco, J.A.F.F.; Aquino, G.L.B.; Silva, V.H.C.; Napolitano, H.B. Synthesis, characterization, and computational study of a new dimethoxy-chalcone. J. Mol. Model. 2014, 20, 2526. [CrossRef]

29. Frisch, M.J.; Trucks, G.W.; Schlegel, H.B.; Scuseria, G.E.; Robb, M.A.; Cheeseman, J.R.; Scalmani, G.; Barone, V.; Mennucci, B.; Petersson, G.A.; et al. Gaussian 09; Revision B.01; Gaussian, Inc.: Wallingford, CT, USA, 2009.

30. Kumar, V.; Gupta, R.; Bansal, A. Role of chenodeoxycholic acid as co-additive in improving the efficiency of DSSCs. Sol. Energy 2020, 196, 589-596. [CrossRef]

31. Nandiyanto, A.B.D.; Oktiani, R.; Ragadhita, R. How to Read and Interpret FTIR Spectroscope of Organic Material. Indones. J. Sci. Technol. 2019, 4, 97-118. [CrossRef]

32. Vinaya, P.; Prabhu, A.; Bhat, K.S.; Upadhyaya, V. Synthesis, growth and characterization of a long-chain $\pi$-conjugation based methoxy chalcone derivative single crystal; a third order nonlinear optical material for optical limiting applications. Opt. Mater. 2019, 89, 419-429. [CrossRef]

33. Thanigaimani, K.; Arshad, S.; Khalib, N.C.; Razak, I.A.; Arunagiri, C.; Subashini, A.; Sulaiman, S.F.; Hashim, N.S.; Ooi, K.L. A new chalcone structure of (E)-1-(4-Bromophenyl)-3-(napthalen-2-yl)prop-2-en-1-one: Synthesis, structural characterizations, quantum chemical investigations and biological evaluations. Spectrochim. Acta Part A. Mol. Biomol. Spectrosc. 2015, 149, 90-102. [CrossRef]

34. Naik, V.S.; Patil, P.S.; Wong, Q.A.; Quah, C.K.; Gummagol, N.B.; Jayanna, H. Molecular structure, linear optical, second and third-order nonlinear optical properties of two non-centrosymmetric thiophene-chalcone derivatives. J. Mol. Struct. 2020, 1222, 128901. [CrossRef]

35. Saravanan, R.R.; Seshadri, S.; Gunasekaran, S.; Mendoza-Meroño, R.; Garcia-Granda, S. Spectrochimica Acta Part A: Molecular and Biomolecular Spectroscopy MEP and molecular docking studies on 1- (1- (3-methoxyphenyl) ethylidene) thiosemicarbazide. Spectrochim. Acta Part A Mol. Biomol. Spectrosc. 2015, 139, 321-328. [CrossRef] [PubMed]

36. Anizaim, A.H.; Arshad, S.; Zaini, M.F.; Abdullah, M.; Zainuri, D.A.; Razak, I.A. Third order nonlinear optical properties of selected fluorinated chalcone derivatives. Opt. Mater. 2019, 98, 109406. [CrossRef]

37. Arshad, S.; Pilli, R.R.; Zainuri, D.A.; Khalib, N.C.; Razak, I.A.; Armaković, S.; Armaković, S.J.; Renjith, R.; Panicker, Y.; Alsenoye, C.V. Synthesis, XRD crystal structure, spectroscopic characterization, local reactive properties using DFT and molecular dynamics simulations and molecular docking study of (E)-1-(4-bromophenyl)-3-(4-(trifluoromethoxy)phenyl)prop-2-en-1-one. J. Mol. Struct. 2017, 1137, 419-430. [CrossRef]

38. Zainuri, D.A.; Abdullah, M.; Arshad, S.; Aziz, M.S.A.; Krishnan, G.; Bakhtiar, H.; Razak, I.A. Crystal structure, spectroscopic and third-order nonlinear optical susceptibility of linear fused ring dichloro-substituent chalcone isomers. Opt. Mater. 2018, 86, 32-45. [CrossRef]

39. Kumar, R.; Kumar, A.; Deval, V.; Gupta, A.; Tandon, P.; Patil, P.S.; Watve, J.G. Molecular structure, spectroscopic (FT-IR, FT Raman, UV, NMR and THz) investigation and hyperpolarizability studies of 3-(2-Chloro-6-fluorophenyl)-1-(2-thienyl) prop-2-en-1-one. J. Mol. Struct. 2017, 1129, 292-304. [CrossRef]

40. Zaini, M.F.; Arshad, S.; Thanigaimani, K.; Khalib, N.C.; Zainuri, D.A.; Abdullah, M.; Razak, I.A. New halogenated chalcones: Synthesis, crystal structure, spectroscopic and theoretical analyses for third-order nonlinear optical properties. J. Mol. Struct. 2019, 1195, 606-619. [CrossRef]

41. Allen, F.H.; Kennard, O.; Watson, D.G.; Brammer, L.; Orpen, A.G.; Taylor, R. Tables of bond lengths determined by X-ray and neutron diffraction. Part 1. Bond lengths in organic compounds. J. Chem. Soc. Perkin Trans. 2 1987, 2, S1-S19. [CrossRef] 
42. Ng, S.-L.; Razak, I.A.; Fun, H.-K.; Patil, P.S.; Dharmaprakash, S.M. 4'-Fluorochalcone. Acta Crystallogr. Sect. E 2006, 62, o2897-o2899. [CrossRef]

43. Fun, H.-K.; Chia, T.S.; Sapnakumari, M.; Narayana, B.; Sarojini, B. (E)-3-(4-Chlorophenyl)-1-(4-fluorophenyl) prop-2-en-1-one. Acta Crystallogr. Sect. E Struct. Rep. Online 2012, 68, o629. [CrossRef]

44. Fun, H.-K.; Farhadikoutenaei, A.; Narayana, B.; Nayak, P.S.; Sarojini, B. (2E)-3-(2-Fluorophenyl)-1-(4-fluorophenyl) prop-2-en-1one. Acta Crystallogr. Sect. E Struct. Rep. Online 2012, 68, o2658. [CrossRef]

45. Alwani Zainuri, D.; Arshad, S.; Che Khalib, N.; Fikri Zaini, M.; Razak, I.A. Molecular Structure Investigation on Organic Chalcone Derivative of (E)-3-(4-Bromothiophen-2-1-(3-nitrophenyl)prop-2-en-1-one: A Combined Experimental and Theoretical Study. J. Phys. Conf. Ser. 2018, 1083, 1. [CrossRef]

46. Velasques, J.M.; Gervini, V.C.; Bortoluzzi, A.J.; De Farias, R.L.; De Oliveira, A.B. Crystal structure of (3E)-5-nitro-3-(2phenylhydrazinylidene)-1H-indol-2(3H)-one. Acta Crystallogr. Sect. E Crystallogr. Commun. 2017, 73, 168-172. [CrossRef]

47. Tripathi, A.; Ganjoo, A.; Chetti, P. Influence of internal acceptor and thiophene based $\pi$-spacer in D-A- $\pi$-A system on photophysical and charge transport properties for efficient DSSCs: A DFT insight. Sol. Energy 2020, 209, 194-205. [CrossRef]

48. Reichardt, C.; Eschner, M.; Schäfer, G. Syntheses and UV-visible spectroscopic properties of new 'fluorophilic' fluorine- and perfluoroalkyl-substituted solvatochromic pyridiniumN-phenolate betaine dyes. J. Phys. Org. Chem. 2001, 14, 737-751. [CrossRef]

49. Zaini, M.F.; Arshad, S.; Ibrahim, A.R.; Khalib, N.C.; Zainuri, D.A. Structural Properties and Quantum Chemical Analysis on a New Chalcone Derivative of (E)-3-(4-bromophenyl)-1-(4-fluorophenyl)prop-2-en-1-one. J. Physics Conf. Ser. 2018, 1083, 012047. [CrossRef]

50. Hossain, M.K.; Pervez, M.F.; Mia, N.H.; Mortuza, A.A.; Rahman, M.S.; Rahaman, M.R.; Karim, M.R.; Islam, J.M.M.; Ahmed, F.; Khan, M.A. Effect of dye extracting solvents and sensitization time on photovoltaic performance of natural dye sensitized solar cells. Results Phys. 2017, 7, 1516-1523. [CrossRef]

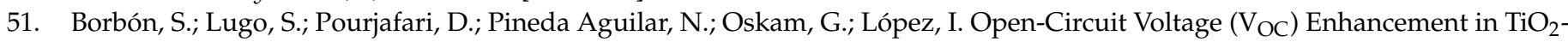
Based DSSCs: Incorporation of ZnO Nanoflowers and Au Nanoparticles. ACS Omega 2020, 5, 10977-10986. [CrossRef] [PubMed]

52. Dao, V.-D. Comment on "Energy storage via polyvinylidene fluoride dielectric on the counter electrode of dye-sensitized solar cells" by Jiang et al. J. Power Sources 2017, 337, 125-129. [CrossRef] 